Article

\title{
Revisiting the Therapeutic Potential of Bothrops jararaca Venom: Screening for Novel Activities Using Connectivity Mapping
}

\author{
Carolina Alves Nicolau ${ }^{1,2,3}$, Alyson Prorock ${ }^{3}$, Yongde Bao ${ }^{3}$, \\ Ana Gisele da Costa Neves-Ferreira ${ }^{1,2}$, Richard Hemmi Valente ${ }^{1,2, *}$ (D) and Jay William Fox ${ }^{3, *}$ \\ 1 Laboratory of Toxinology, Oswaldo Cruz Institute, FIOCRUZ, Rio de Janeiro, RJ 21040-900, Brazil; \\ carolnicolau.bio@gmail.com (C.A.N.); anag@ioc.fiocruz.br (A.G.d.C.N.-F.) \\ 2 National Institute of Science and Technology on Toxins (INCTTOX), CNPq, Brasília, DF 71605-170, Brazil \\ 3 Department of Microbiology, Immunology and Cancer Biology, University of Virginia, Charlottesville, \\ VA 22908, USA; ajp7x@virginia.edu (A.P.); yb8d@virginia.edu (Y.B.) \\ * Correspondence: richardhemmi@gmail.com or rhv4u@ioc.fiocruz.br (R.H.V.); jwf8x@virginia.edu (J.W.F.)
}

Received: 27 November 2017; Accepted: 2 February 2018; Published: 6 February 2018

\begin{abstract}
Snake venoms are sources of molecules with proven and potential therapeutic applications. However, most activities assayed in venoms (or their components) are of hemorrhagic, hypotensive, edematogenic, neurotoxic or myotoxic natures. Thus, other relevant activities might remain unknown. Using functional genomics coupled to the connectivity map (C-map) approach, we undertook a wide range indirect search for biological activities within the venom of the South American pit viper Bothrops jararaca. For that effect, venom was incubated with human breast adenocarcinoma cell line (MCF7) followed by RNA extraction and gene expression analysis. A list of 90 differentially expressed genes was submitted to biosimilar drug discovery based on pattern recognition. Among the 100 highest-ranked positively correlated drugs, only the antihypertensive, antimicrobial (both antibiotic and antiparasitic), and antitumor classes had been previously reported for B. jararaca venom. The majority of drug classes identified were related to (1) antimicrobial activity; (2) treatment of neuropsychiatric illnesses (Parkinson's disease, schizophrenia, depression, and epilepsy); (3) treatment of cardiovascular diseases, and (4) anti-inflammatory action. The C-map results also indicated that $B$. jararaca venom may have components that target G-protein-coupled receptors (muscarinic, serotonergic, histaminergic, dopaminergic, GABA, and adrenergic) and ion channels. Although validation experiments are still necessary, the C-map correlation to drugs with activities previously linked to snake venoms supports the efficacy of this strategy as a broad-spectrum approach for biological activity screening, and rekindles the snake venom-based search for new therapeutic agents.
\end{abstract}

Keywords: Bothrops jararaca; therapeutic potential; connectivity map; drug discovery; biosimilar drugs

Key Contribution: This work has applied connectivity mapping for a biological activity screen in snake venom, leading to the discovery of several new activities with possible therapeutical applications.

\section{Introduction}

The development of therapeutic drugs such as the antihypertensive Captopril ${ }^{\circledR}[1,2]$ and the anticoagulant Exanta ${ }^{\circledR}$ (also known as ximelagatran) [3] can be traced back to the study of isolated snake venom components and their biological roles during envenomation. Over the years, 
venoms, and fractions thereof, have displayed several biological activities/applications, including antibacterial [4-10], antiprotozoarian [7,11-16], antimeasles [17], antiviral (human immunodeficiency virus) [18,19], analgesic [20-24], and for the treatment of multiple sclerosis [25]. It is important to note that some of those aforementioned activities can be related not only to medium to high abundance specific venom toxins but also to low abundance components and, eventually, to their synergistic effects. Also, secondary effects generated by venom components should be considered; such is the case for the activation of inflammation and apoptosis pathways through the action of DAMPs (damage-associated molecular patterns), released after tissue injuries generated by the snake venom/snake venom fraction being assayed [26]. For instance, DAMPs released in the wound exudate after viperid envenomation contribute to vascular permeability mediated by TLR4 (toll-like receptor 4) [27].

The use of functional genomics (microarray techniques) to analyze the subtoxic effects, through gene expression analysis, on cell cultures treated with snake venoms and/or their components has been successfully demonstrated [28,29]. However, it is still challenging to associate signaling pathways identified through functional genomics to the pathophysiology of snakebite (assessed through well-established biochemical and biological assays, screening for hemorrhagic, hypotensive, edematogenic, neurotoxic, and myotoxic activities) [30]. Although these assays are useful in reproducing some of the effects of snakebite envenoming, activities other than those traditionally associated with snake venoms could remain unknown. Hence, without a priori knowledge, it is no simple task to identify potentially novel therapeutic activities derived from snake venoms and/or their components.

An alternative "blind" biological activity screening approach is to use the C-map (connectivity map) platform (https://portals.broadinstitute.org/cmap/). C-map consists in a public database of gene expression patterns generated from the treatment of known cell lineages with 1309 small molecules and drugs, whose pharmacological properties are well characterized [31,32]. Thus, the biological activity of the sample tested can be indirectly inferred by matching the experimental list of differentially expressed genes to the gene expression patterns present in the C-map database. A proof-of-concept for the application of C-map approach in Toxinololgy was demonstrated by treating MCF7 (Michigan cancer foundation 7) cells with Heloderma suspectum (Gila monster) venom or the anti-diabetic drug Byetta (developed from a peptide isolated from that same venom). As predicted, C-map analysis of differentially expressed genes in either condition displayed high positive correlation with different anti-diabetes drugs [33].

Thus, to test the feasibility of C-map analysis for biological activity screening in snake venoms, we chose the venom of the South American pit viper Bothrops jararaca, one of the best characterized venoms by proteomic approaches [34]. Although this venom is highly diverse, few protein classes account for around 94\% of its composition [34] (Table 1). Consequently, the less abundant proteins such as hyaluronidases, cysteine-rich secretory proteins, growth factors, nucleotidases, among others, are underexplored [35,36], resulting in a lack of knowledge about their individual contributions to the snake envenoming pathology. Boldrini-França and colleagues [37] recently emphasized the importance of studying and characterizing minor components from snake venoms, since these can display different potential therapeutical applications, such as: antiparasitic, antitumor, neuroprotection, and ischemic tissue protection.

In this work, we have analyzed the gene expression of MCF7 cells treated with B. jararaca venom and used connectivity mapping to infer novel (therapeutic) activities potentially present in this biological sample. The majority of biosimilar drugs inferred were related to antimicrobial and anti-inflammatory activities, as well as to the treatment of neuropsychiatric and cardiovascular diseases. In short, our data rekindle the snake venom-based search for new therapeutic agents. 
Table 1. Summary information on Bothrops jararaca venom components.

\begin{tabular}{|c|c|c|c|}
\hline Protein Class & Associated Activities & Molecular Mass (kDa) & $\begin{array}{c}\text { Relative } \\
\text { Abundance (\%) }\end{array}$ \\
\hline Metalloendopeptidase & $\begin{array}{l}\text { Degrades extracelular matrix and coagulation } \\
\text { cascade components leading to hemorrhage, } \\
\text { edema, inflammation, and necrosis [38-40] }\end{array}$ & 20-100 & 33.6 \\
\hline Serine endopeptidase & $\begin{array}{l}\text { Acts on platelet aggregation, blood coagulation, } \\
\text { fibrinolysis, complement system, blood } \\
\text { pressure, and the nervous system [41-43] }\end{array}$ & $20-70$ & 22.8 \\
\hline $\begin{array}{l}\text { C-type lectin/C-type } \\
\text { lectin-like }\end{array}$ & $\begin{array}{l}\text { Anticoagulant, procoagulant, } \\
\text { agonist/antagonist of platelet activation [44] }\end{array}$ & $26-124$ & 18.2 \\
\hline Cysteine-rich secretory protein & $\begin{array}{c}\text { Induces inflammatory response and affects the } \\
\text { complement system (anaphylatoxins } \\
\text { generation) }[45,46]\end{array}$ & 25 & 8.2 \\
\hline Phospholipase $\mathrm{A}_{2}$ & $\begin{array}{c}\text { Miotoxicity, neurotoxicity, anticoagulant } \\
\text { effects }[41,47]\end{array}$ & $12-15$ & 6.3 \\
\hline L-amino acid oxidase & $\begin{array}{c}\text { Agonist and antagonist of platelet aggregation; } \\
\text { induces apoptosis [48] }\end{array}$ & $110-150$ & 5.0 \\
\hline $\begin{array}{l}\text { Snake venom vascular } \\
\text { endothelial growth factor }\end{array}$ & Increases vascular permeability $[49,50]$ & 30 & 1.4 \\
\hline $\begin{array}{l}\text { Bradykinin-potentiating- and } \\
\text { C-type-natriuretic peptides }\end{array}$ & $\begin{array}{l}\text { Vasodilatation by inhibition of } \\
\text { angiotensin-converting enzyme }[1,51]\end{array}$ & $<2.5$ & 1.3 \\
\hline Phosphodiesterase & $\begin{array}{l}\text { Pyrimidine and purine release, possibly } \\
\text { contributing to the increase of vascular } \\
\text { permeability }[52,53]\end{array}$ & $100-130$ & $<1.0$ \\
\hline Hyaluronidase & $\begin{array}{c}\text { Degrades the hyaluronic acid present in the } \\
\text { extracellular matrix, facilitating toxin } \\
\text { diffusion [54] }\end{array}$ & $30-80$ & $<1.0$ \\
\hline Ecto-5' ${ }^{\prime}$-nucleotidase & $\begin{array}{l}\text { Pyrimidine and purines release, possibly } \\
\text { contributing to the increase of vascular } \\
\text { permeability [52] }\end{array}$ & 74 & $<1.0$ \\
\hline $\begin{array}{l}\text { Metalloendopeptidase } \\
\text { inhibitor }\end{array}$ & $\begin{array}{l}\text { Inhibits enzymatic and hemorrhagic activity of } \\
\text { snake venom metalloendopeptidases; } \\
\text { abundantly found in the snake's plasma } \\
\text { (protective mechanism) [55] }\end{array}$ & 46 & $<1.0$ \\
\hline Disintegrin & Inhibits platelet aggregation [56] & $4-15$ & $<1.0$ \\
\hline Cobra venom factor $b$ & Activates the complement cascade [57] & 149 & $<1.0$ \\
\hline Three-finger toxin ${ }^{b}$ & $\begin{array}{l}\text { Neurotoxicity and cardiotoxicity effects by } \\
\text { targeting nicotinic and muscarinic } \\
\text { acetylcholinesterase receptors, beta-adrenergic } \\
\text { receptors, and L-type calcium channels }[58,59]\end{array}$ & $6-8$ & $<1$ \\
\hline
\end{tabular}

${ }^{\mathrm{a}}[34]{ }^{\mathrm{b}}$ Major components in venoms from Elapidae snakes, although identified as minor components in $B$. jararaca venom [34].

\section{Results and Discussion}

\subsection{Gene Expression Analysis}

MCF7 cells were used in this work since most of the C-map database information relies on assays using this cell type, due to its extensive molecular characterization and ubiquitous use as a reference cell line [32]. However, since MCF7 cells are not natural targets for snake venom components, it was not the focus of this study to make detailed associations between differentially expressed genes and snakebite envenoming. More importantly, our goal was to submit the list of up- and down-regulated genes to C-map analysis, in order to screen for a panel of biosimilar drug activities related to B. jararaca venom. Nonetheless, we will highlight some of the differentially expressed genes and their possible correlations with snake venom toxins.

B. jararaca venom induced ( $p$-value $<0.01$ ) the differential expression of 90 genes $(74$ up- and 16 down-regulated) in MCF7 cells. We only considered up- or down-regulated genes those displaying a $\log _{2}$ of fold-change equal or greater than 0.58 (fold change $\geq 1.50$ ) or -0.58 (fold change $\leq 0.67$ ), respectively, when compared to expression in the untreated cells (control). The up- and down-regulated genes are shown as supplementary material (Tables S1 and S2, respectively) and the data used to generate these tables are supplied in Tables S5 and S6.

The cytochrome P450 family, which is represented by heme-thiolate proteins [60], displayed the highest differentially expressed gene. The CYP1A1 (cytochrome P450, family 1, subfamily A, 
polypeptide 1) gene had a 29.6-fold increase in expression, compared to control, when MCF7 cells were treated with venom (Table S1). Among the up-regulated genes, we also identified another member of this family, CYP1B1, with 3.4-fold increase. CYP1A1 and CYP1B1 genes are involved in the metabolism of arachidonic acid generating ROS (reactive oxygen species), which is one of the triggers to initiate the apoptosis process [61]. Even though the cytochrome P450 main function is to metabolize drugs and synthesize lipids such as cholesterol and steroids [62], its high expression in MCF7 cells treated with $B$. jararaca venom could also be influenced by three venom components activities through: (i) indirect involvement in the metabolism of arachidonic acid [63] eventually released after PLA 2 (phospholipase $\mathrm{A}_{2}$ ) metabolizes phospholipids [64]; (ii) involvement in the metabolism of arachidonic acid released by the action of bradykinin, which would be possible due to the action of BPPs (bradykinin-potentiating peptides) present in snake venoms [65]; and (iii) use of hydrogen peroxide, released by the action of venom LAAO (L-amino acid oxidase), as an oxygen donor [60]. Those activities may contribute to activation of apoptosis- and inflammatory-related pathways through the generation of ROS. In this regard, the venom from another Viperidae, Echis carinatus, induced an overexpression of genes associated to ROS pathways, including the cytochrome P450 enzymes, in HUVECs (human umbilical vein endothelial cells) [66]. Additionally, B. jararaca and Crotalus atrox venoms induced a significant increase in the expression of genes related to apoptosis and inflammatory pathways in HUVECs [28]. Interestingly, these authors also showed that the proteolytic activity of jararhagin, the major hemorrhagic metalloendopeptidase from $B$. jararaca venom, is mandatory for the generation of an inflammatory and pro-apoptotic response in human fibroblasts [29].

The presence of oxidative stress in MCF7 cells treated with B. jararaca venom is also supported by the significantly higher expression of HMOX1 (heme oxigenase 1) (Table S1), which is an enzyme involved in antioxidant response [67]. HMOX1 degrades heme releasing antioxidant agents such as carbon monoxide and biliverdin (which is further converted to the antioxidant bilirubin) $[68,69]$. Thus, the higher expression of HMOX1 may represent a response to the oxidative stress induced by B. jararaca venom.

Finally, Sunitha and co-workers [26] summarized experimental evidence from the literature for oxidative stress and inflammation induced by viper bites, as well as the apparent involvement of DAMPs, generated after SVMP (snake venom metalloendopeptidase) and PLA 2 activities, in these processes. Recently, it has been confirmed that at least part of the inflammatory process generated after viper bites is dependent on the activation of TLR4 pathway by DAMPs [27].

Overall, it is possible that $B$. jararaca venom induces apoptosis and inflammation through different pathways. The apoptotic feature of snake venoms is likely related to secondary molecules such as $\mathrm{H}_{2} \mathrm{O}_{2}$ released after LAAO activity and $\mathrm{NO}$ (nitric oxide) production. Snake venoms such as B. jararaca and B. asper are able to induce the release of inflammatory mediators like NO [70-72]. Although MCF7 cells do not possess the major molecular targets of snake venoms, and do not produce cytokines, it has been demonstrated that breast cancer cells, including MCF7, express inducible NO synthase [73-75].

\subsection{Connectivity Map Analysis}

We submitted the MCF7/B. jararaca venom genomic signature (list of up- and down-regulated genes following MCF7 cells treatment with venom) to the C-map algorithm for comparison with the gene-expression profiles (signatures) generated by the treatment of different cell lineages with drugs or small molecules, also called perturbagens. In short, the algorithm returns a list of perturbagens (compounds) with score values ranging from +1.000 to -1.000 , encompassing the most positively(agonistic effect) to the most negatively-(antagonistic effect) correlated perturbagens. The C-map score is calculated by a combination of the up and down scores (which represent the absolute enrichment of the list of up- and down-regulated genes, respectively) submitted to the algorithm when compared to the signatures induced by the perturbagen. The C-map score reflects how well the genomic signature induced by the assayed sample correlates with the perturbagens' genomic signatures deposited in the database. In the original publication [31], no statistical treatment has been envisaged following the 
C-map score calculation. Therefore, to ensure low false discovery rates, a reasonable alternative could be to consider only the highest C-map score values (e.g., $>+0.900$ or $<-0.900)$. However, when looking at the data from the literature where, following C-map analysis, biological validation assays have been performed, C-map score values for confirmed hits were as low as 0.530 [31] and -0.777 [76]. The present work established an arbitrary C-map score threshold of 0.600 . On one hand, we acknowledge that, at some instances, this could eventually generate a more speculative discussion. On the other hand, our C-map results (Table S3) displayed positive hits to most of the published biological activities (related to possible therapeutical applications) directly associated to different snake venoms (Table 2), indicating that, as expected, the biological significance of the results has not been impaired by a less stringent cut-off value.

Table 2. Hypothetical activities that could lead to therapeutical applications (identified by the present work) which have already been reported for snake venoms (or fractions thereof).

\begin{tabular}{|c|c|c|}
\hline Activity & Venom Source & Reference \\
\hline Antibacterial & $\begin{array}{l}\text { Bothrops jararaca; } B . \text { asper; B. alternatus; B. atrox; } B . \\
\text { pirajai: Bothropoides lutzi }\end{array}$ & {$[4,8-10,77,78]$} \\
\hline $\begin{array}{l}\text { Anti-parasatic (trypano-, } \\
\text { leishmani-, and plasmodicidal) }\end{array}$ & $\begin{array}{c}\text { B.jararaca; B. moojeni; Crotalus adamanteus; } B . \\
\text { jararacussu; B. asper; B. pirajai; C. durissus collilineatus; } \\
\text { B. marajoensis; B. lutzi; C. d. cumanensis }\end{array}$ & {$[4,11-14,16,77-85]$} \\
\hline Antihypertensive & B. jararaca & {$[1,2,86]$} \\
\hline Antitumor & $\begin{array}{l}\text { B. jararaca; Ophiophagus hannah; Agkistrodon acutus; } \\
\text { Bungarus fasciatus; B. atrox; B. leucurus; C. atrox; } \\
\text { Lachesis muta; A. contortrix laticinctus; } \text { A. halys; A. halys } \\
\text { pallas; B. moojeni; B. pirajai; Calloselasma rhodostoma }\end{array}$ & [87-91] \\
\hline Antiparkinsonian & B. atrox & [92] \\
\hline $\begin{array}{l}\text { Anti-inflammatory and/or } \\
\text { analgesic }\end{array}$ & Naja naja; N. n. atra; C. d. terrificus; O. hannah & {$[20-24,93,94]$} \\
\hline Antidiabetic & $\begin{array}{l}\text { C. adamanteus; C. vegrandis; Bitis nasico; C. d. cascavella; } \\
\text { C. d. terrificus; N. kaouthia; C. d. collilineatus }\end{array}$ & [95-101] \\
\hline
\end{tabular}

Considering only genomic signatures generated by MCF7 cells treated with known drugs, we identified 792 positive correlations, sometimes also described as "agonist-related" activities (Table S7). The top-100 positively correlated drugs are shown in Table S3, and some of them will be discussed below. Additionally, we have rearranged the data from Table S3 according to the major findings and their applications: antimicrobial, anti-inflammatory, and treatment of neuropsychiatric or cardiovascular disorders (Tables 3-6). The top-20 negatively correlated signatures ("antagonist-related") are shown in Table S4.

Table 3. C-map hits for antimicrobial drugs, following MCF7 cells incubation with Bothrops jararaca venom.

\begin{tabular}{cccccc}
\hline C-Map Name & $\begin{array}{c}\text { Dose } \\
(\mathbf{n M})\end{array}$ & Score $^{\mathbf{a}}$ & $\mathbf{U p}^{\mathbf{b}}$ & Down $^{\mathbf{c}}$ & Drug Type \\
\hline Primaquine & $0.9 \times 10^{4}$ & 0.915 & 0.429 & -0.517 & Antiparasite (antimalarian activity) \\
Tanespimycin & $0.1 \times 10^{4}$ & 0.814 & 0.161 & -0.681 & Antineoplastic Antibiotic \\
Cefalonium & $0.9 \times 10^{4}$ & 0.775 & 0.250 & -0.551 & Antibiotic \\
Chlorhexidine & $0.8 \times 10^{4}$ & 0.743 & 0.102 & -0.667 & Antibiotic \\
Novobiocin & $1.0 \times 10^{5}$ & 0.737 & 0.056 & -0.706 & Antibiotic \\
Clioquinol & $1.3 \times 10^{4}$ & 0.737 & 0.366 & -0.396 & Antifungal and antiprotozoal \\
Erythromycin & $0.5 \times 10^{4}$ & 0.721 & 0.119 & -0.627 & Antibiotic \\
Tetracycline & $0.8 \times 10^{4}$ & 0.710 & 0.211 & -0.523 & Antibiotic \\
Piperacillin & $0.7 \times 10^{4}$ & 0.677 & 0.130 & -0.571 & Antibiotic \\
Ciclacillin & $1.2 \times 10^{4}$ & 0.675 & 0.069 & -0.629 & Antibiotic \\
Halofantrine & $0.7 \times 10^{4}$ & 0.675 & 0.146 & -0.552 & Antimalarial \\
Colistin & $0.3 \times 10^{4}$ & 0.665 & 0.167 & -0.521 & Antibiotic \\
\hline
\end{tabular}


Table 3. Cont.

\begin{tabular}{cccccc}
\hline C-Map Name & $\begin{array}{c}\text { Dose } \\
(\mathbf{n M})\end{array}$ & Score $^{\mathbf{a}}$ & $\mathbf{U p}^{\mathbf{b}}$ & Down $^{\mathbf{c}}$ & Drug Type \\
\hline Cefoxitin & $0.9 \times 10^{4}$ & 0.662 & 0.260 & -0.424 & Antibiotic \\
Minocycline & $1.1 \times 10^{4}$ & 0.653 & 0.143 & -0.532 & Antibiotic \\
Azlocillin & $0.8 \times 10^{4}$ & 0.649 & 0.099 & -0.572 & Antibiotic \\
Vancomycin & $0.3 \times 10^{4}$ & 0.646 & 0.096 & -0.572 & Antibiotic \\
Sulfamonomethoxine & $1.4 \times 10^{4}$ & 0.628 & 0.095 & -0.555 & Antibiotic \\
Dicloxacillin & $0.8 \times 10^{4}$ & 0.627 & 0.097 & -0.551 & Antibiotic \\
Hycanthone & $1.1 \times 10^{4}$ & 0.619 & 0.137 & -0.503 & Antischistosomal \\
Ribostamycin & $0.7 \times 10^{4}$ & 0.605 & 0.126 & -0.500 & Antibiotic \\
\hline
\end{tabular}

a Values between +1 and -1 represent the relative strength of a given signature in an instance from the total set of calculated instances; ${ }^{b}$ values between +1 and -1 represent the absolute enrichment of an up tag-list in a given instance; ${ }^{\mathrm{c}}$ values between +1 and -1 represent the absolute enrichment of a down tag-list in a given instance.

Table 4. C-map hits for neuropsychiatric illnesses treatment drugs, following MCF7 cells incubation with Bothrops jararaca venom.

\begin{tabular}{|c|c|c|c|c|c|}
\hline C-Map Name & $\begin{array}{l}\text { Dose } \\
(\mathrm{nM})\end{array}$ & Score $^{\mathrm{a}}$ & $\mathrm{Up}^{\mathrm{b}}$ & Down $^{c}$ & Drug Type \\
\hline Carbamazepine & $1.0 \times 10^{2}$ & 0.803 & 0.219 & -0.611 & $\begin{array}{l}\text { Anticonvulsant (epilepsy and nerve } \\
\text { pain treatment) }\end{array}$ \\
\hline Thioridazine & $1.0 \times 10^{4}$ & 0.802 & 0.241 & -0.589 & $\begin{array}{l}\text { Antipsychotic (schizophrenia } \\
\text { treatment) }\end{array}$ \\
\hline Prochlorperazine & $1.0 \times 10^{4}$ & 0.787 & 0.218 & -0.596 & $\begin{array}{c}\text { Antipsychotic (schizophrenia, } \\
\text { nonpsychotic anxiety treatment) }\end{array}$ \\
\hline Perphenazine & $1.0 \times 10^{4}$ & 0.785 & 0.260 & -0.552 & $\begin{array}{l}\text { Antipsychotic (schizophrenia } \\
\text { treatment) }\end{array}$ \\
\hline Metixene & $1.2 \times 10^{4}$ & 0.778 & 0.302 & -0.503 & Antiparkinsonian \\
\hline Pirlindole & $1.2 \times 10^{4}$ & 0.740 & 0.140 & -0.625 & Antidepressant \\
\hline Mianserin & $1.3 \times 10^{4}$ & 0.726 & 0.226 & -0.525 & Antidepressant \\
\hline Lisuride & $1.2 \times 10^{4}$ & 0.722 & 0.242 & -0.505 & Antiparkinsonian \\
\hline Mesoridazine & $0.7 \times 10^{4}$ & 0.721 & 0.109 & -0.637 & $\begin{array}{l}\text { Antipsychotic (schizophrenia } \\
\text { treatment) }\end{array}$ \\
\hline Clozapine & $1.0 \times 10^{4}$ & 0.712 & 0.109 & -0.627 & $\begin{array}{l}\text { Antipsychotic (treatment-resistant } \\
\text { schizophrenia) }\end{array}$ \\
\hline Trimethadione & $2.8 \times 10^{4}$ & 0.681 & 0.117 & -0.587 & Anticonvulsant (seizures treatment) \\
\hline Zuclopenthixol & $0.9 \times 10^{4}$ & 0.673 & 0.192 & -0.505 & $\begin{array}{l}\text { Antipsychotic (schizophrenia } \\
\text { treatment) }\end{array}$ \\
\hline Haloperidol & $1.0 \times 10^{4}$ & 0.669 & 0.057 & -0.635 & $\begin{array}{l}\text { Antipsychotic (schizophrenia and } \\
\text { Huntington's disease treatment) }\end{array}$ \\
\hline Thioproperazine & $0.6 \times 10^{4}$ & 0.658 & 0.160 & -0.520 & $\begin{array}{l}\text { Antipsychotic (schizophrenia } \\
\text { treatment) }\end{array}$ \\
\hline Diclofenamide & $1.3 \times 10^{4}$ & 0.631 & 0.141 & -0.511 & $\begin{array}{l}\text { Anticonvulsant (antiglaucoma, } \\
\text { antiepileptic) }\end{array}$ \\
\hline Levomepromazine & $0.9 \times 10^{4}$ & 0.627 & 0.214 & -0.434 & $\begin{array}{c}\text { Antipsychotic (schizophrenia, anxiety } \\
\text { treatment) }\end{array}$ \\
\hline Fluphenazine & $1.0 \times 10^{4}$ & 0.623 & 0.284 & -0.361 & $\begin{array}{l}\text { Antipsychotic (psychotic disorders } \\
\text { treatment) }\end{array}$ \\
\hline Valproic Acid & $5.0 \times 10^{4}$ & 0.622 & 0.174 & -0.469 & Anticonvulsant (antiepileptic) \\
\hline Paroxetine & $0.1 \times 10^{4}$ & 0.604 & 0.103 & -0.522 & Antidepressant \\
\hline
\end{tabular}

a Values between +1 and -1 represent the relative strength of a given signature in an instance from the total set of calculated instances; ${ }^{\mathrm{b}}$ values between +1 and -1 represent the absolute enrichment of an up tag-list in a given instance; ${ }^{c}$ values between +1 and -1 represent the absolute enrichment of a down tag-list in a given instance. 
Table 5. C-map hits for cardiovascular disorders treatment drugs, following MCF7 cells incubation with Bothrops jararaca venom.

\begin{tabular}{cccccc}
\hline C-Map Name & $\begin{array}{c}\text { Dose } \\
(\mathbf{n M})\end{array}$ & Score $^{\mathbf{a}}$ & $\mathbf{U p}^{\mathbf{b}}$ & Down $^{\mathbf{c}}$ & Drug Type \\
\hline Clopamide & $1.2 \times 10^{4}$ & 0.771 & 0.126 & -0.671 & Antihypertensive \\
\hline Dobutamine & $1.2 \times 10^{4}$ & 0.714 & 0.126 & -0.612 & $\begin{array}{c}\text { Treatment of heart failure and } \\
\text { cardiogenic shock }\end{array}$ \\
\hline Amrinone & $2.1 \times 10^{4}$ & 0.709 & 0.137 & -0.596 & Vasodilator \\
\hline Quinidine & $1.1 \times 10^{4}$ & 0.702 & 0.112 & -0.614 & Arrhythmias \\
\hline Sotalol & $1.3 \times 10^{4}$ & 0.679 & 0.121 & -0.582 & Arrhythmias \\
\hline Metolazone & $1.1 \times 10^{4}$ & 0.673 & 0.115 & -0.581 & Antihypertensive \\
\hline Papaverine & $1.1 \times 10^{4}$ & 0.652 & 0.133 & -0.542 & Vasodilator \\
\hline Phenoxybenzamine & $1.2 \times 10^{4}$ & 0.637 & 0.247 & -0.413 & Antihypertensive \\
\hline Midodrine & $1.4 \times 10^{4}$ & 0.625 & 0.155 & -0.492 & Antihypotensive \\
\hline Isoprenaline & $1.6 \times 10^{4}$ & 0.617 & 0.148 & -0.490 & Bradycardia \\
\hline Minoxidil & $1.9 \times 10^{4}$ & 0.608 & 0.092 & -0.537 & Arrhythmias \\
\hline Moracizine & $0.9 \times 10^{4}$ & 0.607 & 0.198 & -0.430 & Antihypertensive \\
\hline Hydroflumethiazide & $1.2 \times 10^{4}$ & 0.604 & 0.131 & -0.494 & Arrhythmias \\
\hline Tocainide & $1.7 \times 10^{4}$ & 0.602 & 0.150 & -0.472 & Arrhythmias \\
\hline Practolol & $1.5 \times 10^{4}$ & 0.602 & 0.152 & -0.471 & \\
\hline Values between
\end{tabular}

${ }^{\text {a }}$ Values between +1 and -1 represent the relative strength of a given signature in an instance from the total set of calculated instances; ${ }^{\mathrm{b}}$ values between +1 and -1 represent the absolute enrichment of an up tag-list in a given instance; ${ }^{c}$ values between +1 and -1 represent the absolute enrichment of a down tag-list in a given instance.

Table 6. C-map hits for anti-inflammatory drugs, following MCF7 cells incubation with Bothrops jararaca venom.

\begin{tabular}{cccccc}
\hline C-Map Name & $\begin{array}{c}\text { Dose } \\
(\mathbf{n M})\end{array}$ & Score $^{\mathbf{a}}$ & $\mathbf{U p}^{\mathbf{b}}$ & Down $^{\mathbf{c}}$ & Drug type \\
\hline Sulindac & $1.1 \times 10^{4}$ & 0.854 & 0.330 & -0.553 & Anti-inflammatory \\
Thalidomide & $1.0 \times 10^{5}$ & 0.752 & 0.145 & -0.632 & Anti-inflammatory \\
Oxyphenbutazone & $1.2 \times 10^{4}$ & 0.732 & 0.258 & -0.499 & Anti-inflammatory \\
Tenoxicam & $1.2 \times 10^{4}$ & 0.710 & 0.107 & -0.627 & Anti-inflammatory \\
Epirizole & $1.7 \times 10^{4}$ & 0.700 & 0.152 & -0.572 & Anti-inflammatory \\
Indoprofen & $1.4 \times 10^{4}$ & 0.672 & 0.071 & -0.624 & Anti-inflammatory and analgesic \\
Budesonide & $0.9 \times 10^{4}$ & 0.665 & 0.126 & -0.562 & Anti-inflammatory (Crohn's Disease Treatment) \\
Methylprednisolone & $1.1 \times 10^{4}$ & 0.663 & 0.142 & -0.544 & Anti-inflammatory \\
Mefenamic Acid & $1.7 \times 10^{4}$ & 0.645 & 0.104 & -0.563 & Anti-inflammatory \\
Felbinac & $1.9 \times 10^{4}$ & 0.642 & 0.151 & -0.513 & Anti-inflammatory (analgesic and antipyretic) \\
Acemetacin & $1.0 \times 10^{4}$ & 0.627 & 0.116 & -0.532 & Anti-inflammatory \\
\hline
\end{tabular}

${ }^{a}$ Values between +1 and -1 represent the relative strength of a given signature in an instance from the total set of calculated instances; ${ }^{b}$ values between +1 and -1 represent the absolute enrichment of an up tag-list in a given instance; ${ }^{c}$ values between +1 and -1 represent the absolute enrichment of a down tag-list in a given instance.

\subsubsection{Major Drug Classes Positively Correlated to Venom through C-Map Analysis}

\section{Antimicrobial Activity}

Our biosimilar drug discovery study revealed 20 antimicrobial molecules (Table 3), of which 16 were antibiotics and 4 were antiparasitics (antimalarial, antifungal/antiprotozoal, and antischistosomal).

Antibiotic activity has already been reported for B. jararaca venom against Gram-negative and Gram-positive bacteria [4], as well as in other venoms from the Bothrops genus [8-10]. Additionally, all these studies have associated the antibiotic activity of snake venoms to LAAO or PLA, even though 
their mechanism of action remains unclear. Both enzymes, isolated from different snake venoms (including B. jararaca's) are also frequently associated with anti-parasitic action, such as trypanocidal and leishmanicidal $[4,11,13,14,77,79,80]$.

The second highest positively-correlated drug identified through C-map was primaquine, the only antimalarial drug available to treat malaria relapse caused by Plasmodium vivax [102,103]. This parasite presents a dormant stage (hypnozoite), which remains in the liver, creating a persistent reservoir of infection by subsequently reactivating blood-stage infections [104]. Although primaquine is the current treatment against hypnozoite forms of P. vivax, the drug has limited therapeutic efficacy [105] and is toxic to glucose-6-phosphate dehydrogenase deficient patients, due to the risk of hemolytic anemia [106]. Also, studies have indicated that some hypnozoites may be resistant to primaquine [107]. Thus, the development of more effective antimalarial treatments against hypnozoite stages of $P$. vivax is highly desirable [105]. Furthermore, halofantrine, another antimalarial which acts similarly to chloroquine by forming toxic complexes with ferritoporphyrin IX, thereby damaging the membrane of the parasite [108-110], was also inferred by our C-map data (Table 3).

Although anti-parasitic (Leishmania amazonensis, L. chagas, L. infantum, L. major, Trypanosoma cruzi, and Plasmodium falciparum) activities have already been reported for venoms (and fractions thereof) from different Bothrops genus snakes [14-16,78,79,81-83], an anti-Plasmodium activity had not yet been described specifically for $B$. jararaca venom. However, isolated $\mathrm{PLA}_{2}$ from snake venoms belonging to different genera, including the genus Bothrops, displayed anti-Plasmodium activity $[12,16,84,85]$. It is noteworthy that primaquine induces the expression of CYP1A1 [111], which was the most up-regulated gene identified in this study.

The potential antimalarial activity herein identified may also reflect an effect of HMOX-1, coded by the third most up-regulated gene identified in this work, through heme catabolism (Table S1). HMOX-1 is able to prevent apoptosis through TNF (tumor necrosis factor) pathway in Plasmodium-infected hepatocytes [67]. Studies have indicated that heme might have an important role in Plasmodium survival, especially in the mosquito and in the liver stages of infection, since the parasite is able to synthesize heme, in addition to its capability to obtain heme from the infected erythrocyte [112,113]. Furthermore, carbon monoxide released as a consequence of HMOX-1 enzymatic activity precludes the start of cerebral malaria through binding to hemoglobin released from the cells, thus preventing heme release $[114,115]$.

In summary, some findings of this work corroborate the presence of antimalarial component(s) in B. jararaca venom. They consist of (i) the up-regulation of HMOX1 gene (Table S1) and (ii) the C-map analysis that led to the biosimilar drug discovery of the antimalarials primaquine and halofantrine (Table S3).

\section{Neuropsychiatric Illnesses}

C-map analysis associated B. jararaca venom to 19 drugs used in the treatment of neuropsychiatric disorders; among those, ten antipsychotics, three antidepressants, four anticonvulsants, and two antiparkinsonian drugs (Table 4). These compounds, especially the antipsychotics, usually act on muscarinic, adrenergic, dopaminergic, serotonergic, and/or histaminergic postsynaptic receptors [116-120]. The aforementioned receptors belong to the GPCR (G-protein-coupled receptor) family [121] and they are involved in different cell signal transduction pathways induced by hormones and neurotransmitters [122]. Additionally, the metabotropic glutamate and $\mathrm{GABA}_{\mathrm{B}}$ (gamma-aminobutyric acid, class B) receptors are also described as potential targets for treatment of multiple disorders related to the CNS (central nervous system), such as depression, anxiety disorders, schizophrenia, epilepsy, Alzheimer's, and Parkinson's diseases [123-126].

The potential of snake venom components to treat CNS disorders [127] may be partially explained by the presence of neurotoxins that target muscarinic receptors [128-131] and/or other families of G-protein-coupled receptors [132-135]. Three finger toxins are widely described in venoms of members of the Elapidae family; they act on a great variety of targets, including: (i) muscle nicotinic 
acetylcholine receptor; (ii) neuronal nicotinic receptor; (iii) muscarinic receptor (agonist or antagonist); (iv) acetylcholinesterase (inhibitor); (v) calcium channel; (vi) potassium channel-interacting protein; and (vii) $\beta 1$ - and $\beta 2$-adrenergic receptors [58]. Although 3FTX are primarily described for Elapidae venoms, they were recently identified, albeit in low abundance, in the venom of B. jararaca (Viperidae family) [34]. Thus, it is possible that 3FTX are responsible, at least partially, for the potential of a $B$. jararaca venom isolated component to treat CNS disorders. CRISPs (cysteine-rich secretory proteins) present in Viperidae venoms, including $B$. jararaca, may also contribute to that effect once they target different types of ion channels as well as nicotinic acetylcholine receptors $[45,136]$.

Different drug classes to treat neuropsychiatric illnesses have been associated to the venom; their respective targets are illustrated in Figure 1.

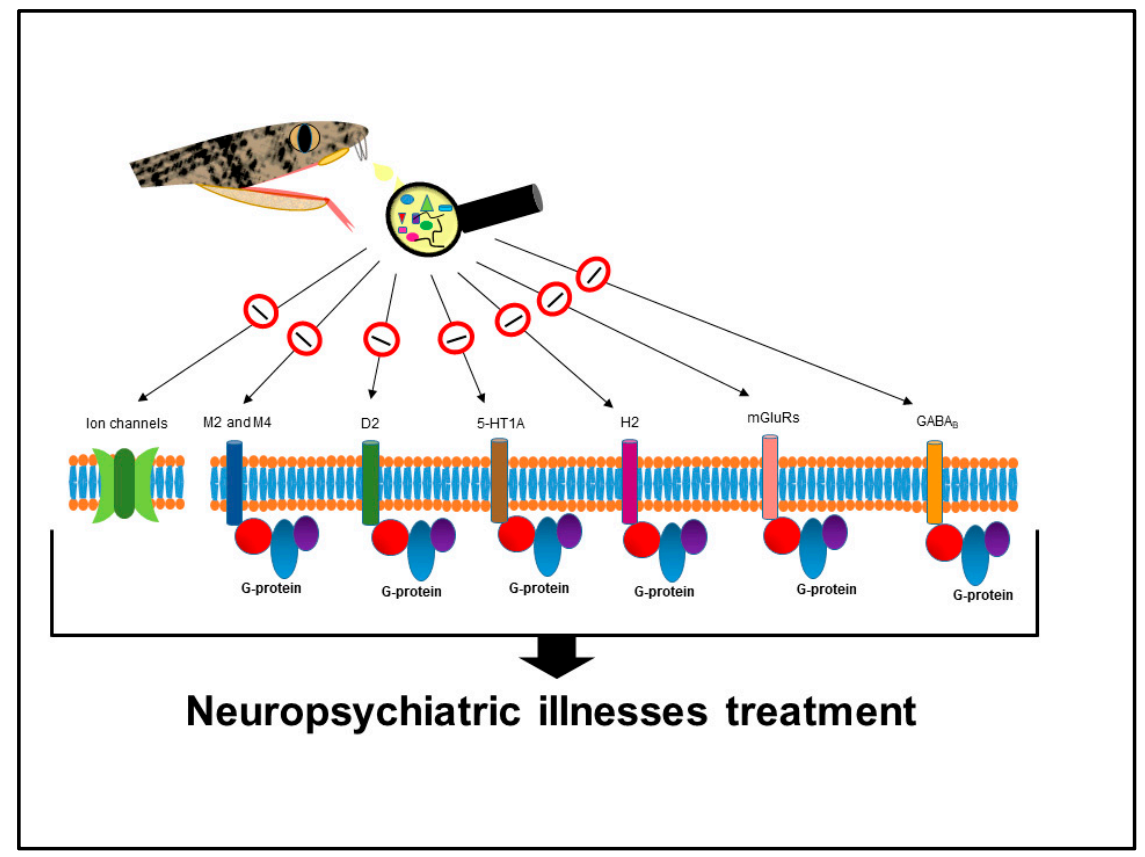

Figure 1. G protein-coupled receptors and ion channels potentially targeted by B. jararaca venom components, as hypothesized by C-map analysis. M2 and M4—subtypes 2 and 4 of muscarinic receptors; D2-subtype 2 of dopaminergic receptor; 5-HT1A—subtype 1A of 5-hydroxytryptamine serotonergic receptor; $\mathrm{H} 2$-subtype 2 of histaminic receptor; mGluRs-metabotropic glutamate receptors; $\mathrm{GABA}_{\mathrm{B}}$ - subtype $\mathrm{B}$ of gamma-aminobutyric acid receptor.

Antipsychotics: Antipsychotics are commonly used to treat schizophrenia primarily through dopamine receptors (especially D2) inhibition [137]. However, they also display varied affinities for serotonin, cholinergic, adrenergic, and histamine receptors [138,139]. The antipsychotics are classified in two categories, typical and atypical. Members of the former category induce high EPS (extrapyramidal side effects) such as acute dystonia, akathisia, parkinsonism, and tardive dyskinesia [140] whereas the atypical ones cause fewer EPS [141]. Clozapine was the only atypical antipsychotic drug identified in the present work. This drug is characterized by a low affinity to dopamine receptors but high affinity for $5 \mathrm{HT}_{2}$ (5-hydroxytryptamine, type 2) serotonin receptor [141,142]. Although clozapine is not the first drug of choice against schizophrenia, it is frequently used to treat drug resistance cases, when the typical antipsychotics have not worked $[143,144]$.

Anticonvulsants: Anticonvulsants are used to treat epilepsy and seizures. Epilepsy is a multifactor neurological disorder characterized by a dysfunction in the speed and intensity of the electrical neuronal discharges leading to unprovoked seizures. Antiepileptic drugs can act in distinct manners: (i) by blocking ion channels, such as voltage activated sodium and T-type calcium channels, and/or 
excitatory amino acids receptors; (ii) by improving the GABA activity as a brain inhibitor [145]. We identified anticonvulsant drugs that target all those pathways: calcium channels (trimethadione), sodium channels (carbamazepine), and GABA (valproic acid). Additionally, we identified a carbonic anhydrase inhibitor (diclofenamide), which is primarily used to treat glaucoma [146]; however, it might be also used to treat epilepsy since the inhibition of carbonic anhydrase, and the consequent increase in brain $\mathrm{CO}_{2}$ level, is a known indirect pathway for epilepsy treatment [147].

Antidepressants: Symptoms of depression are common in medically sick people. However, only a few patients actually undergo a major depressive disorder. This disorder is characterized by disturbances in mood, appetite, and sleep as well as psychomotor compromise, fatigue, and suicidal thoughts, among others [148]. Dysfunctions of norepinephrine and serotonin neurotransmission are frequent in depression and anxiety disorders, which may be explained by the involvement of this neurotransmitter systems in the modulation of other neurobiological systems compromised by this illness [149]. Thus, the antidepressant drugs usually have potent effects on central noradrenergic and serotonergic systems and, in the case of the monoamine oxidase inhibitors, dopaminergic systems as well [150]. Regarding the antidepressants identified in this work, they act by inhibiting $\alpha_{2}$-adrenoceptor receptor (mianserin), serotonin (5-HT) reuptake (paroxetine), and monoamine oxidase A (pirlindole).

Parkinson's Disease Treatment: Parkinson's is a neurodegenerative disorder characterized by a progressive death of dopamine neurons leading to motor disturbances such as muscular rigidity, bradykinesia, and tremor [151,152]. The majority of antiparkinsonian drugs target serotonergic (5-HT1A) and dopaminergic (D2) receptors [153]; such is the case for lisuride, herein identified (Table 4). On the other hand, metixene, also identified in this work, is an anticholinergic drug [154]. As mentioned above (Section 2.2.1-Neuropsychiatric Illnesses) some neurotoxins have affinity for the muscarinic receptors [58]; this might contribute for the potential presence of antiparkinsonian activity in B. jararaca venom. Additionally, it has been shown that a tripeptide (Glu-Val-Trp) isolated from the venom of Bothrops atrox has the potential to decrease apoptosis in a classic model of Parkinson's disease [92]. Considering that the compositions of B. atrox and B. jararaca venoms are related [155], the presence of this peptide and its neuroprotective activity in the venom of $B$. jararaca should be further investigated.

On the other hand, Parkinson's disease patients typically display an accumulation of phosphorylated extracellular protein aggregates. Thus, some authors have suggested that a snake venom metalloendopeptidase, displaying a basic isoelectric point, should be able to cleave these highly phosphorylated protein aggregates, helping to slow the progression of the disease [156].

\section{Cardiovascular Related Disorders}

C-map analysis ascribed, with high positive correlation scores, antihypertensive and vasodilator activities amongst seven different drugs (Table 5). Those activities are usually associated to BPPs [1], which act by blocking the ACE (angiotensin-converting enzyme) [157,158], and had their structure used as a scaffold for development of the anti-hypertensive drug Captopril [2]. Although the hypotensive activity of BPPs is generally associated to ACE inhibition $[157,158]$, BPP 5 a from $B$. jararaca venom induced hypotension through muscarinic and bradykinin receptors [86], both present in MCF7 cells $[159,160]$. Thus, at least part of the antihypertensive activity, indirectly identified through C-map, might be related to BPP 5a. On the other hand, the antihypertensive drugs identified through C-map belong to the alpha-adrenergic blocker (phenoxybenzamine), thiazide diuretic (hydroflumethiazide), and thiazide-like diuretic (clopamide and metolazone) classes [161].

We also identified beta- 1 and / or beta- 2 blockers drugs (practolol and sotalol, Table 5), that are usually used to treat arrhythmias. These results suggest that $B$. jararaca venom could be a source of molecules acting on beta adrenergic receptors, similarly to beta-cardiotoxin, from Ophiophagus hannah venom, which blocks both beta-1 and beta-2 receptors [162]. Interestingly, we also identified beta-1 and beta-2 agonist drugs to treat heart failure/cardiogenic shock and bradycardia, respectively (Table 5). 
It is important to stress that there are other snake venoms compounds such as natriuretic peptides, L-type calcium channels blockers, sarafatoxins, and vascular endothelial growth factors that display cardiovascular effects (reviewed in [163-166]). Two recent works have demonstrated the vasorelaxant effect (which is likely due to the inducing of NO production) of Montivipera bornmuelleri [167] and Crotalus durissus cascavella [168] venoms, indicating their therapeutic potential in the treatment of cardiovascular diseases such as hypertension.

All considered, it is possible that the known antihypertensive activity of $B$. jararaca venom, as well as its potential to treat other cardiovascular related disorders, is more complex than the actual perception, being related to different molecules and/or mechanisms of action, as briefly proposed in Figure 2.

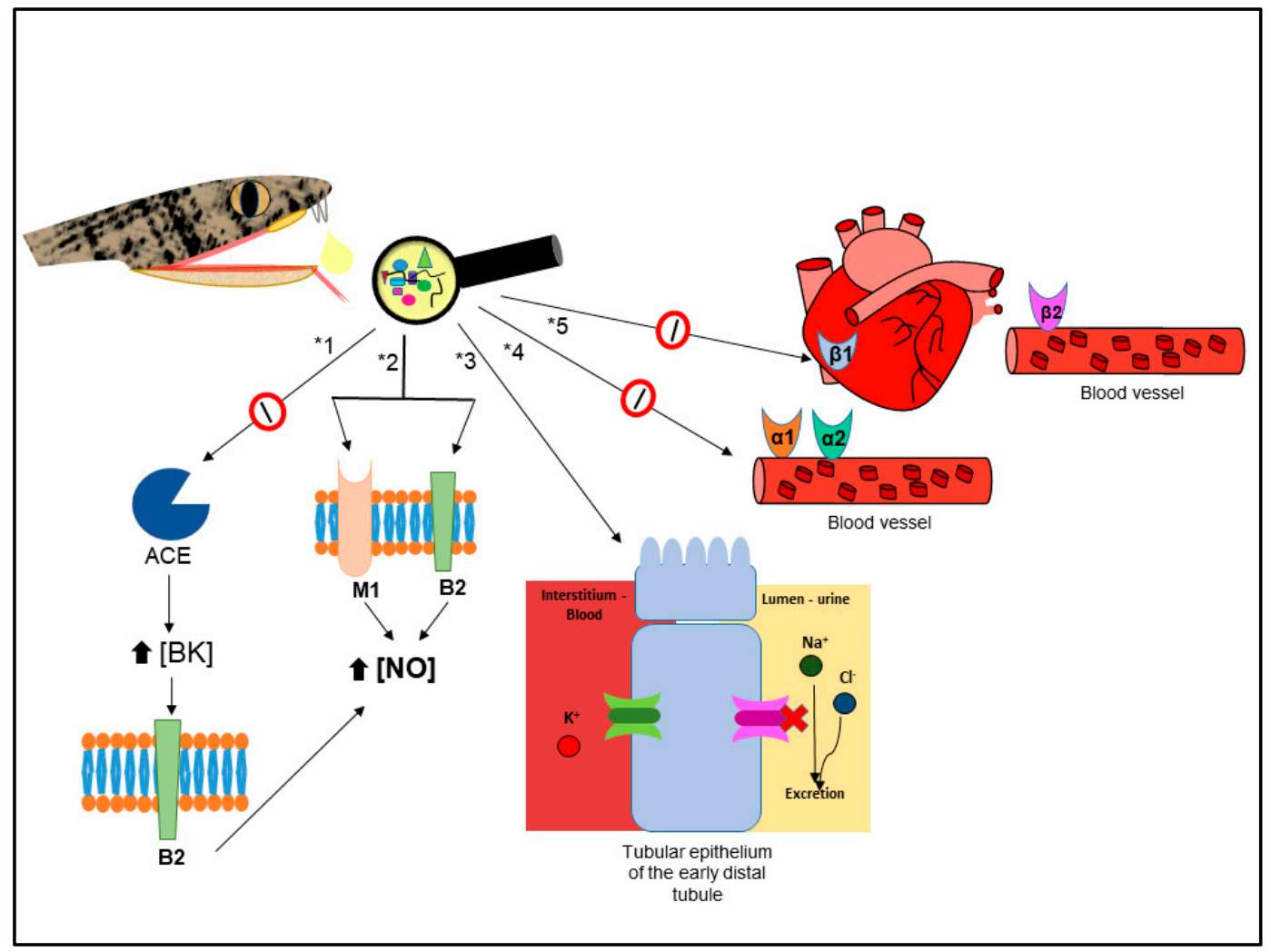

Figure 2. Schematic representation of established and hypothesized (this work) mechanisms of action that contribute to the overall antihypertensive effect of $B$. jararaca venom. ACE-Angiotensin-converting enzyme; BK-bradykinin; B2-subtype 2 of bradykinin receptor; M1-subtype 1 of muscarinic receptor; NO-nitric oxide; $\alpha 1$-subtype 1 of the $\alpha$-adrenergic receptor; $\alpha 2$-subtype 2 of the $\alpha$-adrenergic receptor; $\beta 1$-subtype 1 of the $\beta$-adrenergic receptor; $\beta 2$-subtype 2 of the $\beta$-adrenergic receptor; ${ }^{*} 1$-antihypertensive pathway based on [2]; ${ }^{*}$-antihypertensive pathway based on [118]; *3 to *5-hypotheses, raised after C-map analysis, suggesting that B. jararaca venom may present: $\left({ }^{*} 3\right)$ components acting similarly to thiazide/thiazide-like molecules; $\left({ }^{*} 4\right) \alpha$-adrenergic receptor blockers; and (*5) components inhibiting both $\beta 1$ and $\beta 2$-adrenergic receptors contributing to the antihypertensive effect.

\section{Anti-Inflammatory}

The anti-inflammatory drug Sulindac displayed the third highest positive correlation with B. jararaca venom effects (Table 6). Although this activity was indirectly identified 11 times among the top-100 drugs, its presence in snake venoms is unexpected, since snake venom toxins usually have pro-inflammatory effects $[26,29,169-173]$. However, this activity was recently reported for a cytotoxic protein present in the venom of Naja naja [93], as well as for a known analgesic peptide isolated 
from Naja naja atra venom [94]. A possible explanation would be an indirect action of B. jararaca venom inducing the overexpression of HMOX1, which is able to degrade proinflammatory free heme, generating carbon monoxide, iron, and biliverdin [68]. Additionally, both carbon monoxide and biliverdin, as well as its final product bilirubin, have already been described as anti-inflammatory agents [174-179].

\section{Other Relevant Potential Applications}

Novel Anticancer Drugs: Antitumor activity, herein associated to three drugs against different tumor cell lineages (Table S3), has previously been reported for B. jararaca venom [87]. The antitumor activity of snake venoms may be partially due to LAAO activity. Costa and colleagues recently published a review highlighting the antitumor potential of LAAO [88]. It is hypothesized that LAAO binds preferentially to the tumor cell surface, catalyzes the release of $\mathrm{H}_{2} \mathrm{O}_{2}$ which, once accumulated, induces oxidative stress leading to apoptosis [89]. Recently, Fung and co-workers [90] investigated the molecular mechanisms of antitumor effect of LAAO from Ophiophagus hannah through gene expression analysis of MCF7 cells. They also observed a significant increase in expression of CYP1A1 and, to a lesser extent, of CYP1B1. The authors suggested that both the direct cytotoxic effect of $\mathrm{H}_{2} \mathrm{O}_{2}$ released by LAAO and the oxidative stress are likely the major leading causes of apoptosis and cell death. Nevertheless, another work [91] observed that rusvinoxidase (LAAO from Russell's viper venom) induced apoptosis in MCF7 cells through both extrinsic and intrinsic pathways, which supports the hypothesis for different pathways leading to apoptosis in tumor cells. Although LAAO is probably a key player in the antitumor effect of snake venoms, other components such as SVMPs, disintegrins, $\mathrm{PLA}_{2}$, and C-type lectin/lectin-like proteins are known to have antiangiogenic properties and may also influence the overall antitumor activity [180-183].

Diabetes Treatment: Through C-map analysis, we identified three drugs to treat type II diabetes mellitus (Table S3). Tolbutamide belongs to the sulfonylureas antidiabetic drug class and acts by stimulating $\beta$ cells of the pancreas to release insulin through the inhibition of a potent potassium channel on the $\beta$ cells membrane [184]. Furthermore, troglitazone and rosiglitazone belong to the thiazolidinedione drug class which acts as an agonist of peroxisome proliferator-activated receptors (specifically PPAR $\gamma$ ). This class of antidiabetic drug influences free fatty acid flux, thus reducing insulin resistance and blood glucose levels [185].

"Diabetes mellitus is a group of metabolic diseases characterized by hyperglycemia resulting from defects in insulin secretion, insulin action, or both" [186]. Insulin secretion is modulated by the action of different hormonal and neural stimuli $[95,187,188]$, such as through the activation of G-protein-coupled receptors [189], but also through modulation of ion channel activity [190,191].

It is well known that toxins from venomous animals are able to target a great diversity of G-protein-coupled receptors, such as glucagon receptor family as well as affect membrane excitability through ionic channels modulation [95,134,192]. Thus, the identification of antidiabetic activity was not surprising since insulinotropic properties of snake venoms have already been reported for some components such as $\mathrm{PLA}_{2}$, serine endopeptidases, disintegrins [96], crotamine [97,193], and cardiotoxin [95]. In the case of $\mathrm{PLA}_{2}$, the increase in insulin secretion is likely related to cytosolic $\mathrm{Ca}^{2+}$ [98-100]. On the other hand, crotamine and cardiotoxin act on potassium and sodium ion channels, respectively $[95,101,193]$. It is noteworthy that Byetta ${ }^{\circledR}$, a commercial antidiabetic drug, is a glucagon-like peptide-1 receptor agonist synthesized based on the peptide exendin-4, isolated from the saliva/venom of the Gila monster (Heloderma suspecturn) [194,195]. The potential to treat type II diabetes has also been described for components of wasp [196,197], scorpion [198,199], spider [200], and bee [201] venoms.

Gastroesophageal Reflux Disease Treatment: Gastroesophageal reflux is characterized by movement of harmful gastroduodenal contents such as gastric and bile acids into the esophagus [202]. GERD (gastroesophageal reflux disease) is a condition that causes either esophageal mucosal break, or annoying symptoms such as heartburn and regurgitation, or both $[203,204]$. GERD is usually treated 
by: (i) altering gastric contents by neutralization of acid; (ii) augmenting the antireflux barrier; (iii) improving of mucosal defense mechanisms; (iv) blocking esophageal nociceptors; or (v) modulating afferent signals and their interpretation in the brain cortex [202]. In this work, we indirectly identified one of those treatment pathways: alteration of gastric contents by neutralization of acid.

The drug lansoprazole, which showed the highest positive correlation with $B$. jararaca venom, is a proton pump inhibitor that treats GERD by blocking the gastric acid secretion [205]. However, the identification of lansoprazole may be correlated to its ability to induce the expression of CYP1A1, observed in hepatoma cell line HepG2 [206] and hepatocytes [207]. This ability has already been ascribed to primaquine [111], which was the second highest correlated drug identified (Table S3).

Moreover, H2 (histamine, type 2) receptor antagonists such as ranitidine, another drug related to the venom by $\mathrm{C}$-map, can neutralize the gastric acid secretion dependent of histamine binding to H2 [208]. It has already been shown that the venom of Bothrops moojeni induces edema through the binding of histamine, released by the degranulation of mast cells, to $\mathrm{H} 2$ receptor [209]. Nevertheless, as far as we know, no compound with $\mathrm{H} 2$ antagonist properties has been described in snake venoms so far.

Antihistamines: We identified seven antihistamine drugs (meclozine, chlorphenamine, clemizole, carbinoxamine, ketotifen, mebhydrolin, and diphenhydramine) with good positive correlation with B. jararaca venom (Table S3). All these drugs display an antagonist effect on histamine receptor (H1) [210] but some of them (meclizine and mebhydrolin) have an additional anticholinergic effect. The binding of histamine to $\mathrm{H} 1$ receptor induces a proinflammatory response leading to many effects associated with anaphylaxis and other allergic diseases [211] such as asthma, bronchospasm, and mucosal edema [212]. The antihistaminic activity is unexpected for B. jararaca venom since it contains molecules (e.g., $\mathrm{PLA}_{2}$ and SVMPs) that are able to induce histamine release through mastocyte degranulation [213-216], leading to increased vasodilation and vascular permeability. However, considering that snake venoms can display ambivalent actions such as pro- and anti-coagulant effects or possess both agonists and antagonists of platelet aggregation [41,217], we could hypothesize that snake venoms could display antihistamine activity. It is noteworthy that MCF7 cells express both histamine $\mathrm{H} 1$ and $\mathrm{H} 2$ receptors [218].

\subsubsection{Major Drug Classes Negatively Correlated to Venom through C-Map Analysis}

As previously mentioned, we have also generated a list of negatively correlated genomic signatures following MCF7 cells treatment with the venom (Tables S4 and S7). Although the interpretation of these results is not self-evident, we will comment on some of the hits obtained. For instance, oxymetazoline is a decongestant which acts as an alpha adrenergic agonist [219]. Since there was a negative correlation to venom, one could expect the presence of adrenergic antagonists (blockers). This is consistent with the data discussed in Section 2.2.1-Cardivascular Related Disorders, linking the venom to antihypertensive compounds. Another high-ranking hit was Trapidil, a PDGF (platelet-derived growth factor) antagonist. Although we could not find in the literature a PDGF agonist related to snake venoms, it has been shown that aggretin (a C-type lectin from Calloselasma rhodostoma venom [220]) phosphorylates PDGF receptor beta, leading eventually to PDGF-BB production [221]. Three anti-inflammatory- and one antihistaminic-related drugs could represent the known pro-inflammatory and histamine release activities related to bothropic venoms, which were discussed above (Section 2.2.1-Anti-Inflammatory and Section 2.2.1—Other Relevant Potential Applications: Antihistamines).

\section{Conclusions}

We aimed the exploration of novel potential therapeutic activities in B. jararaca venom through gene expression analysis allied to biological screening using connectivity mapping. The identification of drugs with activities (e.g., antihypertensive, antimicrobial, and antitumoral) previously reported for high abundance components of snake venoms, especially in $B$. jararaca, supported the efficacy 
of C-map as an unbiased exploratory approach for biological activity screening, and rekindles the snake venom-based search for new therapeutic agents. Moreover, this work indicated the existence of active venom components that could potentially be used in the treatment of other disorders (e.g., schizophrenia, depression, epilepsy, and gastroesophageal disease). However, those "newfound" activities should be assayed for in vitro and in vivo (eventually) confirmations, followed by venom fractionation in order to determine the molecular species associated to them. Furthermore, venom prefractionation could be performed and individual fractions submitted to C-map analysis; one such approach would be to assay the complex B. jararaca venom peptidome, recently described in the literature [34]. This peptidome is composed of hundreds of relatively short peptides ( 9 to 10 amino acids long, on average) that could prove a rich bioactive peptide library. In summary, the present work paves the way for further studies exploring the therapeutic potential of snake venoms by providing a rich set of novel activities to be assayed beyond the classical ones (e.g., hemorrhage, myotoxicity, hypotension).

\section{Materials and Methods}

\subsection{Venom}

Lyophilized venom, a pool from several juvenile/adult, male/female Bothrops jararaca specimens, was kindly provided by Instituto Butantan (São Paulo, Brazil). The access to Brazilian fauna genetic heritage was issued by the Conselho Nacional de Desenvolvimento Científico e Tecnológico (CNPq) under license number 010578/2014-5.

\subsection{Tissue Culture}

MCF7 cells were obtained from HTB022 ${ }^{\mathrm{TM}}$ American Type Culture Collection, Manassas, VA and grown in Dulbecco's modified Eagle medium containing $0.01 \mathrm{mg} / \mathrm{mL}$ bovine insulin and $10 \%$ fetal bovine serum. MCF7 cells were passed and grown to $80 \%$ confluence in medium.

\subsection{MCF7 Cells Treatment with B. jararaca Venom}

Initially, one milligram of $B$. jararaca venom was dissolved in $1 \mathrm{~mL}$ of MCF7 medium. Based on previous results with HUVECs [29], four different concentrations $(1,2,5$, and $10 \mu \mathrm{g} / \mathrm{mL})$ were tested. We then chose the highest concentration $(5 \mu \mathrm{g} / \mathrm{mL})$ at which no overt phenotypic changes were observed in the MCF7 cells, and added $1 \mathrm{~mL}$ of this solution to each well on a six-well plate $(85.20 \mathrm{~mm} \times 127.80 \mathrm{~mm})$. After that, the cells were incubated for $6 \mathrm{~h}$ at $37^{\circ} \mathrm{C}$. A plate containing only cells in $1 \mathrm{~mL}$ of media was assayed as control. All experiments were performed in duplicate.

\subsection{Gene Expression Analysis}

The total RNA was extracted from the cells using the RNeasy mini kit (Quiagen, Hilden, Germany, cat. no. 74104) following the manufacturer's instructions. The sense strand DNA was generated from cRNA, fragmented, and labeled for hybridization to HuGene ST 2.0 array (Affimetrix, lot. 4265888, Ref. 902112, Thermo Fisher Scientific, Waltham, MA, USA). The samples were hybridized to the chips overnight and washed and stained using Affymetrix's Fluidics Station 450 (P/N 00-0079, Affymetrix, Santa Clara, CA, USA) and the GeneChip Hybridization, Wash and Stain kit (P/N 900720, Affymetrix) following the manufacturer's instructions. The chips were scanned using Affymetrix's GeneChip Scanner 3000 7G (p/n 00-0213, Affymetrix, Santa Clara, CA, USA). Four chips were run for the two experimental groups (venom and control) assayed in duplicate, as aforementioned.

\subsection{Bioinformatics Analysis}

The gene expression analysis, to determine changes in transcripts following MCF7 cell treatment with B. jararaca in comparison to untreated cells, was carried out as previously described [33]. Furthermore, we also used the C-map software build 02 (https:/ / portals.broadinstitute.org/cmap/) to 
query the probe sets of significantly differentially expressed genes with the perturbagen signatures present in the C-map database. Initially, we converted the probe sets from HuGene ST 2.0 to HGU133A dataset, which is compatible with the C-map database, using the Affymetrix tool that provided a best match between the two chip types.

Afterwards, the algorithm returned a ranked list of all perturbagens found in the C-map database along with scores indicating their relation to the venom. The top-100 positively correlated drugs identified through C-map were submitted to the website Drugbank, available on query (https: / www. drugbank.ca/, (accessed on 12 June 2017) [222], to retrieve information about their mechanisms of action. The same was done to the top-20 negatively correlated drugs.

Supplementary Materials: The following are available online at http:/ /www.mdpi.com/2072-6651/10/2/69/s1, Table S1: Up-regulated MCF7 genes after Bothrops jararaca venom treatment, Table S2: Down-regulated MCF7 genes after Bothrops jararaca venom treatment, Table S3: Top-100 positively correlated C-map hits for drug-related activities potentially present in Bothrops jararaca venom, Table S4: Top-20 negatively correlated C-map hits for drug-related activities potentially present in Bothrops jararaca venom, Table S5: Gene expression profiles induced by Bothrops venom on MCF7 cells, Table S6: Full signal intensities obtained by Bothrops jararaca venom and control (only MCF7 cells), and Table S7: Full C-map hits for drug-related activities identified for Bothrops jararaca venom (only MCF7 cells).

Acknowledgments: This study was supported by PAPES VI/FIOCRUZ grant number 407611/2012-6 and CAPES grant AUXPE 1214/2011. At the time this work was conducted, C.A.N. was a Ph.D. student enrolled in the Cellular and Molecular Biology Graduate Program (Oswaldo Cruz Foundation, FIOCRUZ, Brazil) with a fellowship from CAPES (AUXPE 1214/2011). During that time, she was awarded a 4-month period sandwich fellowship from CAPES (grant number BEX 2832/15-1) to perform experiments at the University of Virginia, USA. A.G.d.C.N-F is a CNPq fellow (311539/2015-7).

Author Contributions: J.W.F., R.H.V., and C.A.N. conceived and designed the experiments; C.A.N. and A.P. performed the experiments; C.A.N., R.H.V., and A.G.d.C.N-F. analyzed the data; Y.B. contributed reagents/materials/analysis tools; C.A.N. and R.H.V. wrote the paper.

Conflicts of Interest: The authors declare no conflict of interest.

\section{References}

1. Ferreira, S.H.; Bartelt, D.C.; Greene, L.J. Isolation of bradykinin-potentiating peptides from Bothrops jararaca venom. Biochemistry 1970, 9, 2583-2593. [CrossRef] [PubMed]

2. Cushman, D.W.; Cheung, H.S.; Sabo, E.F.; Ondetti, M.A. Design of potent competitive inhibitors of angiotensin-converting enzyme. Carboxyalkanoyl and mercaptoalkanoyl amino acids. Biochemistry 1977, 16, 5484-5491. [CrossRef] [PubMed]

3. Hrebickova, L.; Nawarskas, J.J.; Anderson, J.R. Ximelagatran: A new oral anticoagulant. Heart Dis. 2003, 5, 397-408. [CrossRef] [PubMed]

4. Ciscotto, P.; Machado de Avila, R.A.; Coelho, E.A.; Oliveira, J.; Diniz, C.G.; Farias, L.M.; de Carvalho, M.A.; Maria, W.S.; Sanchez, E.F.; Borges, A.; et al. Antigenic, microbicidal and antiparasitic properties of an L-amino acid oxidase isolated from Bothrops jararaca snake venom. Toxicon 2009, 53, 330-341. [CrossRef] [PubMed]

5. Bustillo, S.; Leiva, L.C.; Merino, L.; Acosta, O.; Joffé, E.B.d.K.; Gorodner, J.O. Antimicrobial activity of Bothrops alternatus venom from the Northeast of Argentine. Rev. Latinoam. Microbiol. 2008, 50, 79-82.

6. Torres, A.F.C.; Dantas, R.T.; Menezes, R.R.P.P.B.; Toyama, M.H.; Oliveira, M.F.; Nogueira, N.A.P.; Oliveira, M.R.; Monteiro, H.S.A.; Martins, A.M.C. Antimicrobial activity of an L-amino acid oxidase isolated from Bothrops leucurus snake venom. J. Venom. Anim. Toxins Incl. Trop. Dis. 2010, 16, 614-622. [CrossRef]

7. De Melo Alves Paiva, R.; de Freitas Figueiredo, R.; Antonucci, G.A.; Paiva, H.H.; de Lourdes Pires Bianchi, M.; Rodrigues, K.C.; Lucarini, R.; Caetano, R.C.; Linhari Rodrigues Pietro, R.C.; Gomes Martins, C.H.; et al. Cell cycle arrest evidence, parasiticidal and bactericidal properties induced by L-amino acid oxidase from Bothrops atrox snake venom. Biochimie 2011, 93, 941-947. [CrossRef] [PubMed]

8. Paramo, L.; Lomonte, B.; Pizarro-Cerda, J.; Bengoechea, J.A.; Gorvel, J.P.; Moreno, E. Bactericidal activity of Lys49 and Asp49 myotoxic phospholipases $\mathrm{A}_{2}$ from Bothrops asper snake venom-Synthetic Lys49 myotoxin II-(115-129)-peptide identifies its bactericidal region. Eur. J. Biochem. 1998, 253, 452-461. [CrossRef] [PubMed] 
9. Stabeli, R.G.; Marcussi, S.; Carlos, G.B.; Pietro, R.C.; Selistre-de-Araujo, H.S.; Giglio, J.R.; Oliveira, E.B.; Soares, A.M. Platelet aggregation and antibacterial effects of an L-amino acid oxidase purified from Bothrops alternatus snake venom. Bioorg. Med. Chem. 2004, 12, 2881-2886. [CrossRef] [PubMed]

10. Santamaria, C.; Larios, S.; Quiros, S.; Pizarro-Cerda, J.; Gorvel, J.P.; Lomonte, B.; Moreno, E. Bactericidal and antiendotoxic properties of short cationic peptides derived from a snake venom Lys49 phospholipase $\mathrm{A}_{2}$. Antimicrob. Agents Chemother. 2005, 49, 1340-1345. [CrossRef] [PubMed]

11. Tempone, A.G.; Andrade, H.F., Jr.; Spencer, P.J.; Lourenco, C.O.; Rogero, J.R.; Nascimento, N. Bothrops moojeni venom kills Leishmania spp. with hydrogen peroxide generated by its L-amino acid oxidase. Biochem. Biophys. Res. Commun. 2001, 280, 620-624. [CrossRef] [PubMed]

12. Zieler, H.; Keister, D.B.; Dvorak, J.A.; Ribeiro, J.M. A snake venom phospholipase $\mathrm{A}_{2}$ blocks malaria parasite development in the mosquito midgut by inhibiting ookinete association with the midgut surface. J. Exp. Biol. 2001, 204, 4157-4167. [PubMed]

13. Franca, S.C.; Kashima, S.; Roberto, P.G.; Marins, M.; Ticli, F.K.; Pereira, J.O.; Astolfi-Filho, S.; Stabeli, R.G.; Magro, A.J.; Fontes, M.R.; et al. Molecular approaches for structural characterization of Bothrops L-amino acid oxidases with antiprotozoal activity: CDNA cloning, comparative sequence analysis, and molecular modeling. Biochem. Biophys. Res. Commun. 2007, 355, 302-306. [CrossRef] [PubMed]

14. Deolindo, P.; Teixeira-Ferreira, A.S.; Melo, E.J.; Arnholdt, A.C.; Souza, W.; Alves, E.W.; DaMatta, R.A. Programmed cell death in Trypanosoma cruzi induced by Bothrops jararaca venom. Mem. Inst. Oswaldo Cruz 2005, 100, 33-38. [CrossRef] [PubMed]

15. Deolindo, P.; Teixeira-Ferreira, A.S.; DaMatta, R.A.; Alves, E.W. L-amino acid oxidase activity present in fractions of Bothrops jararaca venom is responsible for the induction of programmed cell death in Trypanosoma cruzi. Toxicon 2010, 56, 944-955. [CrossRef] [PubMed]

16. Castillo, J.C.; Vargas, L.J.; Segura, C.; Gutierrez, J.M.; Perez, J.C. In vitro antiplasmodial activity of phospholipases $\mathrm{A}_{2}$ and a phospholipase homologue isolated from the venom of the snake Bothrops asper. Toxins 2012, 4, 1500-1516. [CrossRef] [PubMed]

17. Petricevich, V.L.; Mendonca, R.Z. Inhibitory potential of Crotalus durissus terrificus venom on measles virus growth. Toxicon 2003, 42, 143-153. [CrossRef]

18. Fenard, D.; Lambeau, G.; Valentin, E.; Lefebvre, J.C.; Lazdunski, M.; Doglio, A. Secreted phospholipases A(2), a new class of HIV inhibitors that block virus entry into host cells. J. Clin. Investig. 1999, 104, 611-618. [CrossRef] [PubMed]

19. Zhang, Y.J.; Wang, J.H.; Lee, W.H.; Wang, Q.; Liu, H.; Zheng, Y.T.; Zhang, Y. Molecular characterization of Trimeresurus stejnegeri venom L-amino acid oxidase with potential anti-HIV activity. Biochem. Biophys. Res. Commun. 2003, 309, 598-604. [CrossRef] [PubMed]

20. Giorgi, R.; Bernardi, M.M.; Cury, Y. Analgesic effect evoked by low molecular weight substances extracted from Crotalus durissus terrificus venom. Toxicon 1993, 31, 1257-1265. [CrossRef]

21. Pu, X.C.; Wong, P.T.; Gopalakrishnakone, P. A novel analgesic toxin (hannalgesin) from the venom of king cobra (Ophiophagus hannah). Toxicon 1995, 33, 1425-1431. [CrossRef]

22. Mancin, A.C.; Soares, A.M.; Andriao-Escarso, S.H.; Faca, V.M.; Greene, L.J.; Zuccolotto, S.; Pela, I.R.; Giglio, J.R. The analgesic activity of crotamine, a neurotoxin from Crotalus durissus terrificus (South American rattlesnake) venom: A biochemical and pharmacological study. Toxicon 1998, 36, 1927-1937. [CrossRef]

23. Chen, Z.X.; Zhang, H.L.; Gu, Z.L.; Chen, B.W.; Han, R.; Reid, P.F.; Raymond, L.N.; Qin, Z.H. A long-form alpha-neurotoxin from cobra venom produces potent opioid-independent analgesia. Acta Pharmacol. Sin. 2006, 27, 402-408. [CrossRef] [PubMed]

24. Jiang, W.J.; Liang, Y.X.; Han, L.P.; Qiu, P.X.; Yuan, J.; Zhao, S.J. Purification and characterization of a novel antinociceptive toxin from Cobra venom (Naja naja atra). Toxicon 2008, 52, 638-646. [CrossRef] [PubMed]

25. Dhanak, A.C.; Rishipathak, D.D.; Gide, P.S. Multiple sclerosis \& it's treatment with alpha-cobratoxin: A review. Int. J. PharmTech Res. 2010, 2, 740-749.

26. Sunitha, K.; Hemshekhar, M.; Thushara, R.M.; Santhosh, M.S.; Sundaram, M.S.; Kemparaju, K.; Girish, K.S. Inflammation and oxidative stress in viper bite: An insight within and beyond. Toxicon 2015, 98, 89-97. [CrossRef] [PubMed]

27. Rucavado, A.; Nicolau, C.A.; Escalante, T.; Kim, J.; Herrera, C.; Gutierrez, J.M.; Fox, J.W. Viperid envenomation wound exudate contributes to increased vascular permeability via a DAMPs/TLR-4 mediated pathway. Toxins 2016, 8, 349. [CrossRef] [PubMed] 
28. Gallagher, P.G.; Bao, Y.; Serrano, S.M.; Kamiguti, A.S.; Theakston, R.D.; Fox, J.W. Use of microarrays for investigating the subtoxic effects of snake venoms: Insights into venom-induced apoptosis in human umbilical vein endothelial cells. Toxicon 2003, 41, 429-440. [CrossRef]

29. Gallagher, P.; Bao, Y.; Serrano, S.M.; Laing, G.D.; Theakston, R.D.; Gutierrez, J.M.; Escalante, T.; Zigrino, P.; Moura-da-Silva, A.M.; Nischt, R.; et al. Role of the snake venom toxin jararhagin in proinflammatory pathogenesis: In vitro and in vivo gene expression analysis of the effects of the toxin. Arch. Biochem. Biophys. 2005, 441, 1-15. [CrossRef] [PubMed]

30. Fox, J.W. Insights in to Venom and Toxin Activities and Pharmacological/Therapeutic Potential Using Gene Expression Profiling. In Toxins and Hemostasis from the Bench to Bedside; Kini, R.M., Clemetson, K.J., Markland, F.S., McLane, M.A., Morita, T., Eds.; Springer: Dordrecht, The Netherlands, 2010; pp. 73-81.

31. Lamb, J.; Crawford, E.D.; Peck, D.; Modell, J.W.; Blat, I.C.; Wrobel, M.J.; Lerner, J.; Brunet, J.P.; Subramanian, A.; Ross, K.N.; et al. The Connectivity Map: Using gene-expression signatures to connect small molecules, genes, and disease. Science 2006, 313, 1929-1935. [CrossRef] [PubMed]

32. Lamb, J. The Connectivity Map: A new tool for biomedical research. Nat. Rev. Cancer 2007, 7, 54-60. [CrossRef] [PubMed]

33. Aramadhaka, L.R.; Prorock, A.; Dragulev, B.; Bao, Y.; Fox, J.W. Connectivity maps for biosimilar drug discovery in venoms: The case of Gila monster venom and the anti-diabetes drug Byetta(R). Toxicon 2013, 69, 160-167. [CrossRef] [PubMed]

34. Nicolau, C.A.; Carvalho, P.C.; Junqueira-de-Azevedo, I.L.; Teixeira-Ferreira, A.; Junqueira, M.; Perales, J.; Neves-Ferreira, A.G.; Valente, R.H. An in-depth snake venom proteopeptidome characterization: Benchmarking Bothrops jararaca. J. Proteom. 2017, 151, 214-231. [CrossRef] [PubMed]

35. Fox, J.W. A brief review of the scientific history of several lesser-known snake venom proteins: L-amino acid oxidases, hyaluronidases and phosphodiesterases. Toxicon 2013, 62, 75-82. [CrossRef] [PubMed]

36. McCleary, R.J.; Kini, R.M. Non-enzymatic proteins from snake venoms: A gold mine of pharmacological tools and drug leads. Toxicon 2013, 62, 56-74. [CrossRef] [PubMed]

37. Boldrini-Franca, J.; Cologna, C.T.; Pucca, M.B.; Bordon, K.C.; Amorim, F.G.; Anjolette, F.A.; Cordeiro, F.A.; Wiezel, G.A.; Cerni, F.A.; Pinheiro-Junior, E.L.; et al. Minor snake venom proteins: Structure, function and potential applications. Biochim. Biophys. Acta 2017, 1861, 824-838. [CrossRef] [PubMed]

38. Bjarnason, J.B.; Fox, J.W. Hemorrhagic metalloproteinases from snake venoms. Pharmacol. Ther. 1994, 62, 325-372. [CrossRef]

39. Jia, Y.; Perez, J.C. Molecular cloning and characterization of cDNAs encoding metalloproteinases from snake venom glands. Toxicon 2010, 55, 462-469. [CrossRef] [PubMed]

40. Fox, J.W.; Serrano, S.M. Structural considerations of the snake venom metalloproteinases, key members of the M12 reprolysin family of metalloproteinases. Toxicon 2005, 45, 969-985. [CrossRef] [PubMed]

41. Kini, R.M. Structure-function relationships and mechanism of anticoagulant phospholipase $\mathrm{A}_{2}$ enzymes from snake venoms. Toxicon 2005, 45, 1147-1161. [CrossRef] [PubMed]

42. Serrano, S.M.; Maroun, R.C. Snake venom serine proteinases: Sequence homology vs. substrate specificity, a paradox to be solved. Toxicon 2005, 45, 1115-1132. [CrossRef] [PubMed]

43. Kini, R.M. Anticoagulant proteins from snake venoms: Structure, function and mechanism. Biochem. J. 2006, 397, 377-387. [CrossRef] [PubMed]

44. Du, X.-Y.; Clemetson, K.J. Reptile C-Type Lectins. In Handbook of Venoms and Toxins of Reptiles; Mackessy, S.P., Ed.; CRC Press: New York, NY, USA, 2010; pp. 359-375.

45. Yamazaki, Y.; Morita, T. Structure and function of snake venom cysteine-rich secretory proteins. Toxicon 2004, 44, 227-231. [CrossRef] [PubMed]

46. Lodovicho, M.E.; Costa, T.R.; Bernardes, C.P.; Menaldo, D.L.; Zoccal, K.F.; Carone, S.E.; Rosa, J.C.; Pucca, M.B.; Cerni, F.A.; Arantes, E.C.; et al. Investigating possible biological targets of Bj-CRP, the first cysteine-rich secretory protein (CRISP) isolated from Bothrops jararaca snake venom. Toxicol. Lett. 2017, 265, 156-169. [CrossRef] [PubMed]

47. Kini, R.M. Excitement ahead: Structure, function and mechanism of snake venom phospholipase $\mathrm{A}_{2}$ enzymes. Toxicon 2003, 42, 827-840. [CrossRef] [PubMed]

48. Du, X.Y.; Clemetson, K.J. Snake venom L-amino acid oxidases. Toxicon 2002, 40, 659-665. [CrossRef] 
49. Junqueira de Azevedo, I.L.; Farsky, S.H.; Oliveira, M.L.; Ho, P.L. Molecular cloning and expression of a functional snake venom vascular endothelium growth factor (VEGF) from the Bothrops insularis pit viper. A new member of the VEGF family of proteins. J. Biol. Chem. 2001, 276, 39836-39842. [CrossRef] [PubMed]

50. Junqueira-de-Azevedo Ide, L.; da Silva, M.B.; Chudzinski-Tavassi, A.M.; Ho, P.L. Identification and cloning of snake venom vascular endothelial growth factor (svVEGF) from Bothrops erythromelas pitviper. Toxicon 2004, 44, 571-575. [CrossRef] [PubMed]

51. Higuchi, S.; Murayama, N.; Saguchi, K.; Ohi, H.; Fujita, Y.; Camargo, A.C.; Ogawa, T.; Deshimaru, M.; Ohno, M. Bradykinin-potentiating peptides and C-type natriuretic peptides from snake venom. Immunopharmacology 1999, 44, 129-135. [CrossRef]

52. Aird, S.D. Ophidian envenomation strategies and the role of purines. Toxicon 2002, 40, 335-393. [CrossRef]

53. Santoro, M.L.; Vaquero, T.S.; Leme, A.F.; Serrano, S.M. NPP-BJ, a nucleotide pyrophosphatase/phosphodiesterase from Bothrops jararaca snake venom, inhibits platelet aggregation. Toxicon 2009, 54, 499-512. [CrossRef] [PubMed]

54. Kemparaju, K.; Girish, K.S. Snake venom hyaluronidase: A therapeutic target. Cell Biochem. Funct. 2006, 24, 7-12. [CrossRef] [PubMed]

55. Valente, R.H.; Dragulev, B.; Perales, J.; Fox, J.W.; Domont, G.B. BJ46a, a snake venom metalloproteinase inhibitor. Isolation, characterization, cloning and insights into its mechanism of action. Eur. J. Biochem. 2001, 268, 3042-3052. [CrossRef] [PubMed]

56. Calvete, J.J. The continuing saga of snake venom disintegrins. Toxicon 2013, 62, 40-49. [CrossRef] [PubMed]

57. Vogel, C.W.; Muller-Eberhard, H.J. Cobra venom factor: Improved method for purification and biochemical characterization. J. Immunol. Methods 1984, 73, 203-220. [CrossRef]

58. Kini, R.M.; Doley, R. Structure, function and evolution of three-finger toxins: Mini proteins with multiple targets. Toxicon 2010, 56, 855-867. [CrossRef] [PubMed]

59. Fry, B.G.; Wuster, W.; Kini, R.M.; Brusic, V.; Khan, A.; Venkataraman, D.; Rooney, A.P. Molecular evolution and phylogeny of elapid snake venom three-finger toxins. J. Mol. Evol. 2003, 57, 110-129. [CrossRef] [PubMed]

60. Hrycay, E.G.; Bandiera, S.M. The monooxygenase, peroxidase, and peroxygenase properties of cytochrome P450. Arch. Biochem. Biophys. 2012, 522, 71-89. [CrossRef] [PubMed]

61. Galluzzi, L.; Kepp, O.; Kroemer, G. Mitochondria: Master regulators of danger signalling. Nat. Rev. Mol. Cell. Biol. 2012, 13, 780-788. [CrossRef] [PubMed]

62. Singh, D.; Kashyap, A.; Pandey, R.V.; Saini, K.S. Novel advances in cytochrome P450 research. Drug Discov. Today 2011, 16, 793-799. [CrossRef] [PubMed]

63. Zordoky, B.N.; El-Kadi, A.O. Effect of cytochrome P450 polymorphism on arachidonic acid metabolism and their impact on cardiovascular diseases. Pharmacol. Ther. 2010, 125, 446-463. [CrossRef] [PubMed]

64. Teixeira, C.F.; Landucci, E.C.; Antunes, E.; Chacur, M.; Cury, Y. Inflammatory effects of snake venom myotoxic phospholipases $A_{2}$. Toxicon 2003, 42, 947-962. [CrossRef] [PubMed]

65. Allen, A.C.; Gammon, C.M.; Ousley, A.H.; McCarthy, K.D.; Morell, P. Bradykinin stimulates arachidonic acid release through the sequential actions of an sn-1 diacylglycerol lipase and a monoacylglycerol lipase. J. Neurochem. 1992, 58, 1130-1139. [CrossRef] [PubMed]

66. Albrecht, E.A.; Dhanasekaran, S.M.; Tomlins, S. Immediate early inflammatory gene responses of human umbilical vein endothelial cells to hemorrhagic venom. Inflamm. Res. 2011, 60, 213-217. [CrossRef] [PubMed]

67. Seixas, E.; Gozzelino, R.; Chora, A.; Ferreira, A.; Silva, G.; Larsen, R.; Rebelo, S.; Penido, C.; Smith, N.R.; Coutinho, A.; et al. Heme oxygenase-1 affords protection against noncerebral forms of severe malaria. Proc. Natl. Acad. Sci. USA 2009, 106, 15837-15842. [CrossRef] [PubMed]

68. Paine, A.; Eiz-Vesper, B.; Blasczyk, R.; Immenschuh, S. Signaling to heme oxygenase-1 and its anti-inflammatory therapeutic potential. Biochem. Pharmacol. 2010, 80, 1895-1903. [CrossRef] [PubMed]

69. Gozzelino, R.; Jeney, V.; Soares, M.P. Mechanisms of cell protection by heme oxygenase-1. Annu Rev. Pharmacol. Toxicol. 2010, 50, 323-354. [CrossRef] [PubMed]

70. Petricevich, V.L.; Teixeira, C.F.; Tambourgi, D.V.; Gutierrez, J.M. Increments in serum cytokine and nitric oxide levels in mice injected with Bothrops asper and Bothrops jararaca snake venoms. Toxicon 2000, 38, 1253-1266. [CrossRef] 
71. Chaves, F.; Teixeira, C.F.; Gutierrez, J.M. Role of TNF-alpha, IL-1beta and IL-6 in the local tissue damage induced by Bothrops asper snake venom: An experimental assessment in mice. Toxicon 2005, 45, 171-178. [CrossRef] [PubMed]

72. Gutierrez, J.M.; Rucavado, A.; Chaves, F.; Diaz, C.; Escalante, T. Experimental pathology of local tissue damage induced by Bothrops asper snake venom. Toxicon 2009, 54, 958-975. [CrossRef] [PubMed]

73. Loibl, S.; von Minckwitz, G.; Weber, S.; Sinn, H.P.; Schini-Kerth, V.B.; Lobysheva, I.; Nepveu, F.; Wolf, G.; Strebhardt, K.; Kaufmann, M. Expression of endothelial and inducible nitric oxide synthase in benign and malignant lesions of the breast and measurement of nitric oxide using electron paramagnetic resonance spectroscopy. Cancer 2002, 95, 1191-1198. [CrossRef] [PubMed]

74. Bulut, A.S.; Erden, E.; Sak, S.D.; Doruk, H.; Kursun, N.; Dincol, D. Significance of inducible nitric oxide synthase expression in benign and malignant breast epithelium: An immunohistochemical study of 151 cases. Virchows Arch. 2005, 447, 24-30. [CrossRef] [PubMed]

75. Choudhari, S.K.; Chaudhary, M.; Bagde, S.; Gadbail, A.R.; Joshi, V. Nitric oxide and cancer: A review. World J. Surg. Oncol. 2013, 11, 118. [CrossRef] [PubMed]

76. Faria, C.C.; Agnihotri, S.; Mack, S.C.; Golbourn, B.J.; Diaz, R.J.; Olsen, S.; Bryant, M.; Bebenek, M.; Wang, X.; Bertrand, K.C.; et al. Identification of alsterpaullone as a novel small molecule inhibitor to target group 3 medulloblastoma. Oncotarget 2015, 6, 21718-21729. [CrossRef] [PubMed]

77. Izidoro, L.F.; Ribeiro, M.C.; Souza, G.R.; Sant'Ana, C.D.; Hamaguchi, A.; Homsi-Brandeburgo, M.I.; Goulart, L.R.; Beleboni, R.O.; Nomizo, A.; Sampaio, S.V.; et al. Biochemical and functional characterization of an L-amino acid oxidase isolated from Bothrops pirajai snake venom. Bioorg. Med. Chem. 2006, 14, 7034-7043. [CrossRef] [PubMed]

78. De Menezes, R.R.; Torres, A.F.; da Silva, T.S.; de Sousa, D.F.; Lima, D.B.; Norjosa, D.B.; Nogueira, N.A.; Oliveira, M.F.; de Oliveira, M.R.; Monteiro, H.S.; et al. Antibacterial and antiparasitic effects of Bothropoides lutzi venom. Nat. Prod. Commun. 2012, 7, 71-74. [PubMed]

79. Goncalves, A.R.; Soares, M.J.; de Souza, W.; DaMatta, R.A.; Alves, E.W. Ultrastructural alterations and growth inhibition of Trypanosoma cruzi and Leishmania major induced by Bothrops jararaca venom. Parasitol. Res. 2002, 88, 598-602. [CrossRef] [PubMed]

80. Passero, L.F.; Laurenti, M.D.; Tomokane, T.Y.; Corbett, C.E.; Toyama, M.H. The effect of phospholipase $\mathrm{A}_{2}$ from Crotalus durissus collilineatus on Leishmania (Leishmania) amazonensis infection. Parasitol. Res. 2008, 102, 1025-1033. [CrossRef] [PubMed]

81. Grabner, A.N.; Alfonso, J.; Kayano, A.M.; Moreira-Dill, L.S.; Dos Santos, A.P.A.; Caldeira, C.A.S.; Sobrinho, J.C.; Gomez, A.; Grabner, F.P.; Cardoso, F.F.; et al. BmajPLA2-II, a basic Lys49-phospholipase $\mathrm{A}_{2}$ homologue from Bothrops marajoensis snake venom with parasiticidal potential. Int. J. Biol. Macromol. 2017, 102, 571-581. [CrossRef] [PubMed]

82. Carone, S.E.I.; Costa, T.R.; Burin, S.M.; Cintra, A.C.O.; Zoccal, K.F.; Bianchini, F.J.; Tucci, L.F.F.; Franco, J.J.; Torqueti, M.R.; Faccioli, L.H.; et al. A new L-amino acid oxidase from Bothrops jararacussu snake venom: Isolation, partial characterization, and assessment of pro-apoptotic and antiprotozoal activities. Int. J. Biol. Macromol. 2017, 103, 25-35. [CrossRef] [PubMed]

83. Mello, C.P.; Lima, D.B.; Menezes, R.R.; Bandeira, I.C.; Tessarolo, L.D.; Sampaio, T.L.; Falcao, C.B.; Radis-Baptista, G.; Martins, A.M. Evaluation of the antichagasic activity of batroxicidin, a cathelicidin-related antimicrobial peptide found in Bothrops atrox venom gland. Toxicon 2017, 130, 56-62. [CrossRef] [PubMed]

84. Guillaume, C.; Deregnaucourt, C.; Clavey, V.; Schrevel, J. Anti-Plasmodium properties of group IA, IB, IIA and III secreted phospholipases $\mathrm{A}_{2}$ are serum-dependent. Toxicon 2004, 43, 311-318. [CrossRef] [PubMed]

85. Quintana, J.C.; Chacon, A.M.; Vargas, L.; Segura, C.; Gutierrez, J.M.; Alarcon, J.C. Antiplasmodial effect of the venom of Crotalus durissus cumanensis, crotoxin complex and Crotoxin B. Acta Trop. 2012, 124, 126-132. [CrossRef] [PubMed]

86. Morais, K.L.; Hayashi, M.A.; Bruni, F.M.; Lopes-Ferreira, M.; Camargo, A.C.; Ulrich, H.; Lameu, C. Bj-PRO-5a, a natural angiotensin-converting enzyme inhibitor, promotes vasodilatation mediated by both bradykinin B(2)and M1 muscarinic acetylcholine receptors. Biochem. Pharmacol. 2011, 81, 736-742. [CrossRef] [PubMed]

87. Da Silva, C.A.; Kassel, O.; Mathieu, E.; Massard, G.; Gasser, B.; Frossard, N. Inhibition by glucocorticoids of the interleukin-1beta-enhanced expression of the mast cell growth factor SCF. Br. J. Pharmacol. 2002, 135, 1634-1640. [CrossRef] [PubMed] 
88. Costa, T.R.; Burin, S.M.; Menaldo, D.L.; de Castro, F.A.; Sampaio, S.V. Snake venom L-amino acid oxidases: An overview on their antitumor effects. J. Venom. Anim. Toxins Incl. Trop. Dis. 2014, 20, 23. [CrossRef] [PubMed]

89. Ande, S.R.; Kommoju, P.R.; Draxl, S.; Murkovic, M.; Macheroux, P.; Ghisla, S.; Ferrando-May, E. Mechanisms of cell death induction by L-amino acid oxidase, a major component of ophidian venom. Apoptosis 2006, 11, 1439-1451. [CrossRef] [PubMed]

90. Fung, S.Y.; Lee, M.L.; Tan, N.H. Molecular mechanism of cell death induced by king cobra (Ophiophagus hannah) venom L-amino acid oxidase. Toxicon 2015, 96, 38-45. [CrossRef] [PubMed]

91. Mukherjee, A.K.; Saviola, A.J.; Burns, P.D.; Mackessy, S.P. Apoptosis induction in human breast cancer (MCF-7) cells by a novel venom L-amino acid oxidase (Rusvinoxidase) is independent of its enzymatic activity and is accompanied by caspase-7 activation and reactive oxygen species production. Apoptosis 2015, 20, 1358-1372. [CrossRef] [PubMed]

92. Martins, N.M.; Santos, N.A.; Sartim, M.A.; Cintra, A.C.; Sampaio, S.V.; Santos, A.C. A tripeptide isolated from Bothrops atrox venom has neuroprotective and neurotrophic effects on a cellular model of Parkinson's disease. Chem. Biol. Interact. 2015, 235, 10-16. [CrossRef] [PubMed]

93. Gomes, A.; Datta, P.; Das, T.; Biswas, A.K. Anti arthritic and anti inflammatory activity of a cytotoxic protein NN-32 from Indian spectacle cobra (Naja naja) venom in male albino rats. Toxicon 2014, 90, 106-110. [CrossRef] [PubMed]

94. Ruan, Y.; Yao, L.; Zhang, B.; Zhang, S.; Guo, J. Anti-inflammatory effects of Neurotoxin-Nna, a peptide separated from the venom of Naja naja atra. BMC Complement. Altern. Med. 2013, 13, 86. [CrossRef] [PubMed]

95. Nguyen, T.T.; Folch, B.; Letourneau, M.; Vaudry, D.; Truong, N.H.; Doucet, N.; Chatenet, D.; Fournier, A. Cardiotoxin-I: An unexpectedly potent insulinotropic agent. Chembiochem 2012, 13, 1805-1812. [CrossRef] [PubMed]

96. Moore, S.W.; Bhat, V.K.; Flatt, P.R.; Gault, V.A.; McClean, S. Isolation and characterisation of insulin-releasing compounds from Crotalus adamanteus, Crotalus vegrandis and Bitis nasicornis venom. Toxicon 2015, 101, 48-54. [CrossRef] [PubMed]

97. Toyama, O.D.; Boschero, C.A.; Martins, A.M.; Fonteles, C.M.; Monteiro, S.H.; Toyama, H.M. Structure-function relationship of new crotamine isoform from the Crotalus durissus cascavella. Protein J. 2005, 24, 9-19. [CrossRef] [PubMed]

98. Lajus, S.; Vacher, P.; Huber, D.; Dubois, M.; Benassy, M.N.; Ushkaryov, Y.; Lang, J. Alpha-latrotoxin induces exocytosis by inhibition of voltage-dependent $\mathrm{K}+$ channels and by stimulation of L-type Ca2+ channels via latrophilin in beta-cells. J. Biol. Chem. 2006, 281, 5522-5531. [CrossRef] [PubMed]

99. Yamamoto, S.; Nakaki, T.; Nakadate, T.; Kato, R. Insulinotropic effects of exogenous phospholipase $\mathrm{A}_{2}$ and C in isolated pancreatic islets. Eur. J. Pharmacol. 1982, 86, 121-124. [CrossRef]

100. Nogueira, T.C.; Ferreira, F.; Toyama, M.H.; Stoppiglia, L.F.; Marangoni, S.; Boschero, A.C.; Carneiro, E.M. Characterization of the insulinotropic action of a phospholipase $\mathrm{A}_{2}$ isolated from Crotalus durissus collilineatus rattlesnake venom on rat pancreatic islets. Toxicon 2005, 45, 243-248. [CrossRef] [PubMed]

101. Nicastro, G.; Franzoni, L.; de Chiara, C.; Mancin, A.C.; Giglio, J.R.; Spisni, A. Solution structure of crotamine, a Na+ channel affecting toxin from Crotalus durissus terrificus venom. Eur. J. Biochem. 2003, 270, 1969-1979. [CrossRef] [PubMed]

102. WHO. Global Report on Antimalarial Drug Efficacy and Drug Resistance: 2000-2010; World Health Organization: Geneva, Switzerland, 2010.

103. WHO. Guidelines for Malaria Treatment; World Health Organization: Geneva, Switzerland, 2015.

104. Baird, J.K.; Rieckmann, K.H. Can primaquine therapy for vivax malaria be improved? Trends Parasitol. 2003, 19, 115-120. [CrossRef]

105. Price, R.N.; Douglas, N.M.; Anstey, N.M.; von Seidlein, L. Plasmodium vivax treatments: What are we looking for? Curr. Opin. Infect. Dis. 2011, 24, 578-585. [CrossRef] [PubMed]

106. Howes, R.E.; Battle, K.E.; Satyagraha, A.W.; Baird, J.K.; Hay, S.I. G6PD deficiency: Global distribution, genetic variants and primaquine therapy. Adv. Parasitol. 2013, 81, 133-201. [PubMed]

107. Thomas, D.; Tazerouni, H.; Sundararaj, K.G.; Cooper, J.C. Therapeutic failure of primaquine and need for new medicines in radical cure of Plasmodium vivax. Acta Trop. 2016, 160, 35-38. [CrossRef] [PubMed] 
108. Fitch, C.D.; Chevli, R.; Banyal, H.S.; Phillips, G.; Pfaller, M.A.; Krogstad, D.J. Lysis of Plasmodium falciparum by ferriprotoporphyrin IX and a chloroquine-ferriprotoporphyrin IX complex. Antimicrob. Agents Chemother. 1982, 21, 819-822. [CrossRef] [PubMed]

109. De Villiers, K.A.; Marques, H.M.; Egan, T.J. The crystal structure of halofantrine-ferriprotoporphyrin IX and the mechanism of action of arylmethanol antimalarials. J. Inorg. Biochem. 2008, 102, 1660-1667. [CrossRef] [PubMed]

110. Dorn, A.; Vippagunta, S.R.; Matile, H.; Jaquet, C.; Vennerstrom, J.L.; Ridley, R.G. An assessment of drug-haematin binding as a mechanism for inhibition of haematin polymerisation by quinoline antimalarials. Biochem. Pharmacol. 1998, 55, 727-736. [CrossRef]

111. Werlinder, V.; Backlund, M.; Zhukov, A.; Ingelman-Sundberg, M. Transcriptional and post-translational regulation of CYP1A1 by primaquine. J. Pharmacol. Exp. Ther. 2001, 297, 206-214. [PubMed]

112. Nagaraj, V.A.; Sundaram, B.; Varadarajan, N.M.; Subramani, P.A.; Kalappa, D.M.; Ghosh, S.K.; Padmanaban, G. Malaria parasite-synthesized heme is essential in the mosquito and liver stages and complements host heme in the blood stages of infection. PLoS Pathog. 2013, 9, e1003522. [CrossRef] [PubMed]

113. Ke, H.; Sigala, P.A.; Miura, K.; Morrisey, J.M.; Mather, M.W.; Crowley, J.R.; Henderson, J.P.; Goldberg, D.E.; Long, C.A.; Vaidya, A.B. The heme biosynthesis pathway is essential for Plasmodium falciparum development in mosquito stage but not in blood stages. J. Biol. Chem. 2014, 289, 34827-34837. [CrossRef] [PubMed]

114. Pamplona, A.; Ferreira, A.; Balla, J.; Jeney, V.; Balla, G.; Epiphanio, S.; Chora, A.; Rodrigues, C.D.; Gregoire, I.P.; Cunha-Rodrigues, M.; et al. Heme oxygenase-1 and carbon monoxide suppress the pathogenesis of experimental cerebral malaria. Nat. Med. 2007, 13, 703-710. [CrossRef] [PubMed]

115. Ferreira, I.D.; Martinelli, A.; Rodrigues, L.A.; do Carmo, E.L.; do Rosario, V.E.; Povoa, M.M.; Cravo, P. Plasmodium falciparum from Pará state (Brazil) shows satisfactory in vitro response to artemisinin derivatives and absence of the S769N mutation in the SERCA-type PfATPase6. Trop. Med. Int. Health 2008, 13, 199-207. [CrossRef] [PubMed]

116. Sivaraman, P.; Rattehalli, R.D.; Jayaram, M.B. Levomepromazine for schizophrenia. Cochrane Database Syst. Rev. 2010. [CrossRef]

117. Bymaster, F.P.; Felder, C.C.; Tzavara, E.; Nomikos, G.G.; Calligaro, D.O.; McKinzie, D.L. Muscarinic mechanisms of antipsychotic atypicality. Prog. Neuropsychopharmacol. Biol. Psychiatry 2003, 27, 1125-1143. [CrossRef] [PubMed]

118. Thanacoody, R.H. Thioridazine: The good and the bad. Recent Pat. Anti-Infect. Drug Discov. 2011, 6, 92-98. [CrossRef]

119. Jayakody, K.; Gibson, R.C.; Kumar, A.; Gunadasa, S. Zuclopenthixol acetate for acute schizophrenia and similar serious mental illnesses. Cochrane Database Syst. Rev. 2012, 4, CD000525. [CrossRef] [PubMed]

120. Tardy, M.; Huhn, M.; Engel, R.R.; Leucht, S. Fluphenazine versus low-potency first-generation antipsychotic drugs for schizophrenia. Cochrane Database Syst. Rev. 2014, 8, CD009230. [CrossRef] [PubMed]

121. Selbie, L.A.; Hill, S.J. G protein-coupled-receptor cross-talk: The fine-tuning of multiple receptor-signalling pathways. Trends Pharmacol. Sci. 1998, 19, 87-93. [CrossRef]

122. Rosenbaum, D.M.; Rasmussen, S.G.; Kobilka, B.K. The structure and function of G-protein-coupled receptors. Nature 2009, 459, 356-363. [CrossRef] [PubMed]

123. Niswender, C.M.; Conn, P.J. Metabotropic glutamate receptors: Physiology, pharmacology, and disease. Annu. Rev. Pharmacol. Toxicol. 2010, 50, 295-322. [CrossRef] [PubMed]

124. Cryan, J.F.; Kaupmann, K. Don't worry 'B' happy!: A role for GABA(B) receptors in anxiety and depression. Trends Pharmacol. Sci. 2005, 26, 36-43. [CrossRef] [PubMed]

125. Bettler, B.; Kaupmann, K.; Mosbacher, J.; Gassmann, M. Molecular structure and physiological functions of GABA(B) receptors. Physiol. Rev. 2004, 84, 835-867. [CrossRef] [PubMed]

126. Kumar, K.; Sharma, S.; Kumar, P.; Deshmukh, R. Therapeutic potential of GABA(B) receptor ligands in drug addiction, anxiety, depression and other CNS disorders. Pharmacol. Biochem. Behav. 2013, 110, 174-184. [CrossRef] [PubMed]

127. Da Silva, D.C.; de Medeiros, W.A.; Batista Ide, F.; Pimenta, D.C.; Lebrun, I.; Abdalla, F.M.; Sandoval, M.R. Characterization of a new muscarinic toxin from the venom of the Brazilian coral snake Micrurus lemniscatus in rat hippocampus. Life Sci. 2011, 89, 931-938. [CrossRef] [PubMed] 
128. Liang, J.S.; Carsi-Gabrenas, J.; Krajewski, J.L.; McCafferty, J.M.; Purkerson, S.L.; Santiago, M.P.; Strauss, W.L.; Valentine, H.H.; Potter, L.T. Anti-muscarinic toxins from Dendroaspis angusticeps. Toxicon 1996, 34, 1257-1267. [CrossRef]

129. Bradley, K.N. Muscarinic toxins from the green mamba. Pharmacol. Ther. 2000, 85, 87-109. [CrossRef]

130. Karlsson, E.; Jolkkonen, M.; Mulugeta, E.; Onali, P.; Adem, A. Snake toxins with high selectivity for subtypes of muscarinic acetylcholine receptors. Biochimie 2000, 82, 793-806. [CrossRef]

131. Servent, D.; Fruchart-Gaillard, C. Muscarinic toxins: Tools for the study of the pharmacological and functional properties of muscarinic receptors. J. Neurochem. 2009, 109, 1193-1202. [CrossRef] [PubMed]

132. Maiga, A.; Merlin, J.; Marcon, E.; Rouget, C.; Larregola, M.; Gilquin, B.; Fruchart-Gaillard, C.; Lajeunesse, E.; Marchetti, C.; Lorphelin, A.; et al. Orthosteric binding of rho-Da1a, a natural peptide of snake venom interacting selectively with the alpha1A-adrenoceptor. PLoS ONE 2013, 8, e68841. [CrossRef] [PubMed]

133. Maiga, A.; Mourier, G.; Quinton, L.; Rouget, C.; Gales, C.; Denis, C.; Lluel, P.; Senard, J.M.; Palea, S.; Servent, D.; et al. G protein-coupled receptors, an unexploited animal toxin targets: Exploration of green mamba venom for novel drug candidates active against adrenoceptors. Toxicon 2012, 59, 487-496. [CrossRef] [PubMed]

134. Nareoja, K.; Nasman, J. Selective targeting of G-protein-coupled receptor subtypes with venom peptides. Acta Physiol. 2011, 204, 186-201. [CrossRef] [PubMed]

135. Blanchet, G.; Upert, G.; Mourier, G.; Gilquin, B.; Gilles, N.; Servent, D. New alpha-adrenergic property for synthetic MTbeta and CM-3 three-finger fold toxins from black mamba. Toxicon 2013, 75, 160-167. [CrossRef] [PubMed]

136. Gorbacheva, E.V.; Starkov, V.G.; Tsetlin, V.I.; Utkin, Y.N.; Vulfius, C.A. Viperidae Snake Venoms Block Nicotinic Acetylcholine Receptors and Voltage-Gated $\mathrm{Ca}^{2+}$ Channels in Identified Neurons of Fresh-Water Snail Lymnaea stagnalis. Biochem. (Mosc.) Suppl. Ser. A Membr. Cell Biol. 2008, 2, 14-18.

137. Lally, J.; MacCabe, J.H. Antipsychotic medication in schizophrenia: A review. Br. Med. Bull. 2015, 114, 169-179. [CrossRef] [PubMed]

138. Milelli, A.; Turrini, E.; Catanzaro, E.; Maffei, F.; Fimognari, C. Perspectives in Designing Multifunctional Molecules in Antipsychotic Drug Discovery. Drug Dev. Res. 2016, 77, 437-443. [CrossRef] [PubMed]

139. Horacek, J.; Bubenikova-Valesova, V.; Kopecek, M.; Palenicek, T.; Dockery, C.; Mohr, P.; Hoschl, C. Mechanism of action of atypical antipsychotic drugs and the neurobiology of schizophrenia. CNS Drugs 2006, 20, 389-409. [CrossRef] [PubMed]

140. Divac, N.; Prostran, M.; Jakovcevski, I.; Cerovac, N. Second-generation antipsychotics and extrapyramidal adverse effects. Biomed. Res. Int. 2014, 2014, 656370. [CrossRef] [PubMed]

141. Meltzer, H.Y. The role of serotonin in antipsychotic drug action. Neuropsychopharmacology 1999, 21, 106S-115S. [CrossRef]

142. Meltzer, H.Y. Clinical studies on the mechanism of action of clozapine: The dopamine-serotonin hypothesis of schizophrenia. Psychopharmacology 1989, 99, S18-S27. [CrossRef] [PubMed]

143. Kane, J.M.; Honigfeld, G.; Singer, J.; Meltzer, H. Clozapine in treatment-resistant schizophrenics. Psychopharmacol. Bull. 1988, 24, 62-67. [CrossRef] [PubMed]

144. Kane, J.M.; Correll, C.U. The Role of Clozapine in Treatment-Resistant Schizophrenia. JAMA Psychiatry 2016, 73, 187-188. [CrossRef] [PubMed]

145. Ayati, A.; Emami, S.; Foroumadi, A. The importance of triazole scaffold in the development of anticonvulsant agents. Eur. J. Med. Chem. 2016, 109, 380-392. [CrossRef] [PubMed]

146. Masini, E.; Carta, F.; Scozzafava, A.; Supuran, C.T. Antiglaucoma carbonic anhydrase inhibitors: A patent review. Expert Opin. Ther. Pat. 2013, 23, 705-716. [CrossRef] [PubMed]

147. Aggarwal, M.; Kondeti, B.; McKenna, R. Anticonvulsant/antiepileptic carbonic anhydrase inhibitors: A patent review. Expert Opin. Ther. Pat. 2013, 23, 717-724. [CrossRef] [PubMed]

148. Cosci, F.; Fava, G.A.; Sonino, N. Mood and anxiety disorders as early manifestations of medical illness: A systematic review. Psychother. Psychosom. 2014, 84, 22-29. [CrossRef] [PubMed]

149. Sliz, D.; Hayley, S. Major depressive disorder and alterations in insular cortical activity: A review of current functional magnetic imaging research. Front. Hum. Neurosci. 2012, 6, 323. [CrossRef] [PubMed]

150. Morilak, D.A.; Frazer, A. Antidepressants and brain monoaminergic systems: A dimensional approach to understanding their behavioural effects in depression and anxiety disorders. Int. J. Neuropsychopharmacol. 2004, 7, 193-218. [CrossRef] [PubMed] 
151. Dickson, D.W. Parkinson's disease and parkinsonism: Neuropathology. Cold Spring Harb. Perspect. Med. 2012, 2, a009258. [CrossRef] [PubMed]

152. Alexander, G.E. Biology of Parkinson's disease: Pathogenesis and pathophysiology of a multisystem neurodegenerative disorder. Dialogues Clin. Neurosci. 2004, 6, 259-280. [PubMed]

153. Ye, Z.; Altena, E.; Nombela, C.; Housden, C.R.; Maxwell, H.; Rittman, T.; Huddleston, C.; Rae, C.L.; Regenthal, R.; Sahakian, B.J.; et al. Selective serotonin reuptake inhibition modulates response inhibition in Parkinson's disease. Brain 2014, 137, 1145-1155. [CrossRef] [PubMed]

154. Syvalahti, E.K.; Kunelius, R.; Lauren, L. Effects of antiparkinsonian drugs on muscarinic receptor binding in rat brain, heart and lung. Pharmacol. Toxicol. 1988, 62, 90-94. [CrossRef] [PubMed]

155. Sousa, L.F.; Nicolau, C.A.; Peixoto, P.S.; Bernardoni, J.L.; Oliveira, S.S.; Portes-Junior, J.A.; Mourao, R.H.; Lima-Dos-Santos, I.; Sano-Martins, I.S.; Chalkidis, H.M.; et al. Comparison of phylogeny, venom composition and neutralization by antivenom in diverse species of Bothrops complex. PLoS Negl. Trop. Dis. 2013, 7, e2442. [CrossRef] [PubMed]

156. Gasanov, S.E.; Dagda, R.K.; Rael, E.D. Snake venom cytotoxins, phospholipase $\mathrm{A}_{2} \mathrm{~s}$, and $\mathrm{Zn}^{2+}$-dependent metalloproteinases: mechanisms of action and pharmacological relevance. J. Clin. Toxicol. 2014, 4, 1000181. [CrossRef] [PubMed]

157. Villard, E.; Soubrier, F. Molecular biology and genetics of the angiotensin-I-converting enzyme: Potential implications in cardiovascular diseases. Cardiovasc. Res. 1996, 32, 999-1007. [CrossRef]

158. Cotton, J.; Hayashi, M.A.; Cuniasse, P.; Vazeux, G.; Ianzer, D.; De Camargo, A.C.; Dive, V. Selective inhibition of the C-domain of angiotensin I converting enzyme by bradykinin potentiating peptides. Biochemistry 2002, 41, 6065-6071. [CrossRef] [PubMed]

159. Fiszman, G.L.; Middonno, M.C.; de la Torre, E.; Farina, M.; Espanol, A.J.; Sales, M.E. Activation of muscarinic cholinergic receptors induces MCF-7 cells proliferation and angiogenesis by stimulating nitric oxide synthase activity. Cancer Biol. Ther. 2007, 6, 1106-1113. [CrossRef] [PubMed]

160. Da Costa, P.L.; Sirois, P.; Tannock, I.F.; Chammas, R. The role of kinin receptors in cancer and therapeutic opportunities. Cancer Lett. 2014, 345, 27-38. [CrossRef] [PubMed]

161. Michel, T.; Hoffman, B.B. Goodman E Gilman's The Pharmacological Basis of Therapeutics, 12th ed.; Brunton, L.L., Chabner, B.A., Knollman, B.C., Eds.; McGraw-Hill: New York, NY, USA, 2011; pp. 745-788.

162. Rajagopal, V.; Kreitman, R.J. Recombinant toxins that bind to the urokinase receptor are cytotoxic without requiring binding to the a2-macroglobulin receptor. J. Biol. Chem. 2000, 275, 7566-7573. [CrossRef] [PubMed]

163. Lewis, R.J.; Garcia, M.L. Therapeutic potential of venom peptides. Nat. Rev. Drug Discov. 2003, 2, 790-802. [CrossRef] [PubMed]

164. Joseph, R.; Pahari, S.; Hodgson, W.C.; Kini, R.M. Hypotensive agents from snake venoms. Curr. Drug Targets Cardiovasc. Haematol. Disord. 2004, 4, 437-459. [CrossRef] [PubMed]

165. Koh, C.Y.; Kini, R.M. From snake venom toxins to therapeutics-Cardiovascular examples. Toxicon 2011, 59, 497-506. [CrossRef] [PubMed]

166. Horta, C.C.R.; Chatzaki, M.; Rezende, B.A.; Magalhães, B.F.; Duarte, C.G.; Felicori, L.F.; Oliveira-Mendes, B.B.R.; do Carmo, A.O.; hávez-Olórtegui, C.; Kalapothakis, E. Cardiovascular-Active Venom Toxins: An Overview. Curr. Med. Chem. 2016, 23, 603-622. [CrossRef]

167. Accary, C.; Hraoui-Bloquet, S.; Sadek, R.; Alameddine, A.; Fajloun, Z.; Desfontis, J.C.; Mallem, Y. The relaxant effect of the Montivipera bornmuelleri snake venom on vascular contractility. J. Venom. Res. 2016, 7, 10-15. [PubMed]

168. Santos, S.S.; Jesus, R.L.C.; Simoes, L.O.; Vasconcelos, W.P.; Medeiros, I.A.; Veras, R.C.; Casais, E.S.L.L.; Silva, D.F. NO production and potassium channels activation induced by Crotalus durissus cascavella underlie mesenteric artery relaxation. Toxicon 2017, 133, 10-17. [CrossRef] [PubMed]

169. Tambourgi, D.V.; dos Santos, M.C.; Furtado Mde, F.; de Freitas, M.C.; da Silva, W.D.; Kipnis, T.L. Pro-inflammatory activities in elapid snake venoms. Br. J. Pharmacol. 1994, 112, 723-727. [CrossRef] [PubMed]

170. Teixeira, C.F.P.; Fernandes, C.M.; Zuliani, J.P.; Zamuner, S.F. Inflammatory effects of snake venom metalloproteinases. Mem. Inst. Butantan 2005, 100, 181-184. [CrossRef]

171. Moura-da-Silva, A.M.; Butera, D.; Tanjoni, I. Importance of snake venom metalloproteinases in cell biology: Effects on platelets, inflammatory and endothelial cells. Curr. Pharm. Des. 2007, 13, 2893-2905. [CrossRef] [PubMed] 
172. Nunes, D.C.; Rodrigues, R.S.; Lucena, M.N.; Cologna, C.T.; Oliveira, A.C.; Hamaguchi, A.; Homsi-Brandeburgo, M.I.; Arantes, E.C.; Teixeira, D.N.; Ueira-Vieira, C.; et al. Isolation and functional characterization of proinflammatory acidic phospholipase $\mathrm{A}_{2}$ from Bothrops leucurus snake venom. Comp. Biochem. Physiol. C Toxicol. Pharmacol. 2011, 154, 226-233. [CrossRef] [PubMed]

173. Gutierrez, J.M.; Escalante, T.; Rucavado, A.; Herrera, C.; Fox, J.W. A comprehensive view of the structural and functional alterations of extracellular matrix by snake venom metalloproteinases (SVMPs): Novel perspectives on the pathophysiology of envenoming. Toxins 2016, 8, 304. [CrossRef] [PubMed]

174. Alcaraz, M.J.; Fernandez, P.; Guillen, M.I. Anti-inflammatory actions of the heme oxygenase-1 pathway. Curr. Pharm. Des. 2003, 9, 2541-2551. [CrossRef] [PubMed]

175. Otterbein, L.E.; Choi, A.M. Heme oxygenase: Colors of defense against cellular stress. Am. J. Physiol. Lung. Cell. Mol. Physiol. 2000, 279, L1029-L1037. [CrossRef] [PubMed]

176. Gullotta, F.; di Masi, A.; Coletta, M.; Ascenzi, P. CO metabolism, sensing, and signaling. Biofactors 2012, 38, 1-13. [CrossRef] [PubMed]

177. Motterlini, R.; Green, C.J.; Foresti, R. Regulation of heme oxygenase-1 by redox signals involving nitric oxide. Antioxid. Redox Signal. 2002, 4, 615-624. [CrossRef] [PubMed]

178. Zhu, X.; Fan, W.G.; Li, D.P.; Kung, H.; Lin, M.C. Heme oxygenase-1 system and gastrointestinal inflammation: A short review. World J. Gastroenterol. 2011, 17, 4283-4288. [CrossRef] [PubMed]

179. Wegiel, B.; Otterbein, L.E. Go green: The anti-inflammatory effects of biliverdin reductase. Front. Pharmacol. 2012, 3, 47. [CrossRef] [PubMed]

180. Jain, D.; Kumar, S. Snake venom: A potent anticancer agent. Asian Pac. J. Cancer Prev. 2012, 13, 4855-4860. [CrossRef] [PubMed]

181. Calderon, L.A.; Sobrinho, J.C.; Zaqueo, K.D.; de Moura, A.A.; Grabner, A.N.; Mazzi, M.V.; Marcussi, S.; Nomizo, A.; Fernandes, C.F.; Zuliani, J.P.; et al. Antitumoral activity of snake venom proteins: New trends in cancer therapy. Biomed. Res. Int. 2014, 2014, 203639. [CrossRef] [PubMed]

182. Lucena, S.; Castro, R.; Lundin, C.; Hofstetter, A.; Alaniz, A.; Suntravat, M.; Sanchez, E.E. Inhibition of pancreatic tumoral cells by snake venom disintegrins. Toxicon 2015, 93, 136-143. [CrossRef] [PubMed]

183. Dhananjaya, B.L.; Sivashankari, P.R. Snake venom derived molecules in tumor angiogenesis and its application in cancer therapy; an overview. Curr. Top. Med. Chem. 2015, 15, 649-657. [CrossRef] [PubMed]

184. Mizuno, C.S.; Chittiboyina, A.G.; Kurtz, T.W.; Pershadsingh, H.A.; Avery, M.A. Type 2 diabetes and oral antihyperglycemic drugs. Curr. Med. Chem. 2008, 15, 61-74. [PubMed]

185. Staels, B.; Fruchart, J. Therapeutic Roles of Peroxisome Proliferator-Activated Receptor Agonists. Diabetes 2005, 54, 2460-2470. [CrossRef] [PubMed]

186. American Association Diabetes. Standards of medical care in diabetes-2009. Diabetes Care 2009, 32 (Suppl. 1), S13-S61.

187. Chandra, R.; Liddle, R.A. Neural and hormonal regulation of pancreatic secretion. Curr. Opin. Gastroenterol. 2009, 25, 441-446. [CrossRef] [PubMed]

188. Fu, Z.; Gilbert, E.R.; Liu, D. Regulation of insulin synthesis and secretion and pancreatic Beta-cell dysfunction in diabetes. Curr. Diabetes Rev. 2013, 9, 25-53. [CrossRef] [PubMed]

189. Madiraju, S.R.; Poitout, V. G protein-coupled receptors and insulin secretion: 119 and counting. Endocrinology 2007, 148, 2598-2600. [CrossRef] [PubMed]

190. Boyd, A.E., III. The Role of Ion Channels in Insulin Secretion. J. Cell. Biochem. 1992, 48, 234-241. [CrossRef]

191. Fridlyand, L.E.; Jacobson, D.A.; Philipson, L.H. Ion channels and regulation of insulin secretion in human $\beta$-cells: A computational systems analysis. Islets 2013, 5, 1-15. [CrossRef] [PubMed]

192. Diaz-Garcia, C.M.; Sanchez-Soto, C.; Hiriart, M. Toxins that modulate ionic channels as tools for exploring insulin secretion. Cell. Mol. Neurobiol. 2010, 30, 1275-1281. [CrossRef] [PubMed]

193. Toyama, M.H.; Carneiro, E.M.; Marangoni, S.; Barbosa, R.L.; Corso, G.; Boschero, A.C. Biochemical characterization of two crotamine isoforms isolated by a single step RP-HPLC from Crotalus durissus terrificus (South American rattlesnake) venom and their action on insulin secretion by pancreatic islets. Biochim. Biophys. Acta 2000, 1474, 56-60. [CrossRef]

194. Eng, J.; Kleinman, W.A.; Singh, L.; Singh, G.; Raufman, J.P. Isolation and characterization of exendin-4, an exendin-3 analogue, from Heloderma suspectum venom. Further evidence for an exendin receptor on dispersed acini from guinea pig pancreas. J. Biol. Chem. 1992, 267, 7402-7405. [PubMed] 
195. Furman, B.L. The development of Byetta (exenatide) from the venom of the Gila monster as an anti-diabetic agent. Toxicon 2012, 59, 464-471. [CrossRef] [PubMed]

196. Amin, R.H.; Chen, H.Q.; Veluthakal, R.; Silver, R.B.; Li, J.; Li, G.; Kowluru, A. Mastoparan-induced insulin secretion from insulin-secreting betaTC3 and INS-1 cells: Evidence for its regulation by Rho subfamily of G proteins. Endocrinology 2003, 144, 4508-4518. [CrossRef] [PubMed]

197. Baptista-Saidemberg, N.B.; Saidemberg, D.M.; Ribeiro, R.A.; Arcuri, H.A.; Palma, M.S.; Carneiro, E.M. Agelaia MP-I: A peptide isolated from the venom of the social wasp, Agelaia pallipes pallipes, enhances insulin secretion in mice pancreatic islets. Toxicon 2012, 60, 596-602. [CrossRef] [PubMed]

198. Sankaran, H.; Deveney, C.W.; Bartholomew, C.; Raghupathy, E. Action of the venom of the scorpion Tityus trinitatis on pancreatic insulin secretion. Biochem. Pharmacol. 1983, 32, 1101-1104. [CrossRef]

199. Goncalves, A.A.; Toyama, M.H.; Carneiro, E.M.; Marangoni, S.; Arantes, E.C.; Giglio, J.R.; Boschero, A.C. Participation of $\mathrm{Na}^{+}$channels in the potentiation by Tityus serrulatus alpha-toxin TsTx-V of glucose-induced electrical activity and insulin secretion in rodent islet beta-cells. Toxicon 2003, 41, 1039-1045. [CrossRef]

200. Holz, G.G.; Habener, J.F. Black widow spider alpha-latrotoxin: A presynaptic neurotoxin that shares structural homology with the glucagon-like peptide-1 family of insulin secretagogic hormones. Comp. Biochem. Physiol. B Biochem. Mol. Biol. 1998, 121, 177-184. [CrossRef]

201. Mousavi, S.M.; Imani, S.; Haghighi, S.; Mousavi, S.E.; Karimi, A. Effect of Iranian Honey bee (Apis mellifera) Venom on Blood Glucose and Insulin in Diabetic Rats. J. Arthropod-Borne Dis. 2013, 6, 136-143.

202. Vela, M.F. Medical treatments of GERD: The old and new. Gastroenterol. Clin. N. Am. 2014, 43, $121-133$. [CrossRef] [PubMed]

203. Iwakiri, K.; Kinoshita, Y.; Habu, Y.; Oshima, T.; Manabe, N.; Fujiwara, Y.; Nagahara, A.; Kawamura, O.; Iwakiri, R.; Ozawa, S.; et al. Evidence-based clinical practice guidelines for gastroesophageal reflux disease 2015. J. Gastroenterol. 2016, 51, 751-767. [CrossRef] [PubMed]

204. Patrick, L. Gastroesophageal reflux disease (GERD): A review of conventional and alternative treatments. Altern. Med. Rev. 2011, 16, 116-133. [PubMed]

205. Gremse, D.A. Lansoprazole: Pharmacokinetics, pharmacodynamics and clinical uses. Expert Opin. Pharmacother. 2001, 2, 1663-1670. [CrossRef] [PubMed]

206. Krusekopf, S.; Kleeberg, U.; Hildebrandt, A.G.; Ruckpaul, K. Effects of benzimidazole derivatives on cytochrome P450 1A1 expression in a human hepatoma cell line. Xenobiotica 1997, 27, 1-9. [CrossRef] [PubMed]

207. Curi-Pedrosa, R.; Daujat, M.; Pichard, L.; Ourlin, J.C.; Clair, P.; Gervot, L.; Lesca, P.; Domergue, J.; Joyeux, H.; Fourtanier, G.; et al. Omeprazole and lansoprazole are mixed inducers of CYP1A and CYP3A in human hepatocytes in primary culture. J. Pharmacol. Exp. Ther. 1994, 269, 384-392. [PubMed]

208. Van der Pol, R.; Langendam, M.; Benninga, M.; van Wijk, M.; Tabbers, M. Efficacy and safety of histamine-2 receptor antagonists. JAMA Pediatr. 2014, 168, 947-954. [CrossRef] [PubMed]

209. Galvao Nascimento, N.; Sampaio, M.C.; Amaral Olivo, R.; Teixeira, C. Contribution of mast cells to the oedema induced by Bothrops moojeni snake venom and a pharmacological assessment of the inflammatory mediators involved. Toxicon 2010, 55, 343-352. [CrossRef] [PubMed]

210. Simons, F.E. The antiallergic effects of antihistamines (H1-receptor antagonists). J. Allergy Clin. Immunol. 1992, 90, 705-715. [CrossRef]

211. Stojković, N.; Cekić, S.; Ristov, M.; Ristić, M.; Đukić, D.; Binić, M.; Virijević, D. Histamine and Antihistamines. Sci. J. Fac. Med. 2015, 32, 7-22.

212. Xie, H.; He, S.H. Roles of histamine and its receptors in allergic and inflammatory bowel diseases. World J. Gastroenterol. 2005, 11, 2851-2857. [CrossRef] [PubMed]

213. Damerau, B.; Lege, L.; Oldigs, H.D.; Vogt, W. Histamine release, formation of prostaglandin-like activity (SRS-C) and mast cell degranulation by the direct lytic factor (DLF) and phospholipase A of cobra venom. Naunyn-Schmiedeberg's Arch. Pharmacol. 1975, 287, 141-156. [CrossRef]

214. Chen, I.J.; Chiu, H.F.; Huang, H.T.; Teng, C.M. Edema formation and degranulation of mast cells by Trimeresurus mucrosquamatus snake venom. Toxicon 1984, 22, 17-28. [CrossRef]

215. Wei, J.F.; Mo, Y.Z.; Qiao, L.Y.; Wei, X.L.; Chen, H.Q.; Xie, H.; Fu, Y.L.; Wang, W.Y.; Xiong, Y.L.; He, S.H. Potent histamine-releasing activity of atrahagin, a novel snake venom metalloproteinase. Int. J. Biochem. Cell Biol. 2006, 38, 510-520. [CrossRef] [PubMed] 
216. Bonavita, A.G.; da Costa, A.S.; Pires, A.L.; Neves-Ferreira, A.G.; Perales, J.; Cordeiro, R.S.; Martins, M.A.; e Silva, P.M. Contribution of mast cells and snake venom metalloproteinases to the hyperalgesia induced by Bothrops jararaca venom in rats. Toxicon 2006, 47, 885-893. [CrossRef] [PubMed]

217. Ogawa, T.; Chijiwa, T.; Oda-Ueda, N.; Ohno, M. Molecular diversity and accelerated evolution of C-type lectin-like proteins from snake venom. Toxicon 2005, 45, 1-14. [CrossRef] [PubMed]

218. Medina, V.A.; Rivera, E.S. Histamine receptors and cancer pharmacology. Br. J. Pharmacol. 2010, 161, 755-767. [CrossRef] [PubMed]

219. Corboz, M.R.; Mutter, J.C.; Rivelli, M.A.; Mingo, G.G.; McLeod, R.L.; Varty, L.; Jia, Y.; Cartwright, M.; Hey, J.A. $\alpha 2$-adrenoceptor agonists as nasal decongestants. Pulm. Pharmacol. Ther. 2007, 20, 149-156. [CrossRef] [PubMed]

220. Chung, C.H.; Au, L.C.; Huang, T.F. Molecular cloning and sequence analysis of aggretin, a collagen-like platelet aggregation inducer. Biochem. Biophys. Res. Commun. 1999, 263, 723-727. [CrossRef] [PubMed]

221. Chung, C.H.; Lin, K.T.; Chang, C.H.; Peng, H.C.; Huang, T.F. The integrin alpha2beta1 agonist, aggretin, promotes proliferation and migration of VSMC through NF-kB translocation and PDGF production. Br. J. Pharmacol. 2009, 156, 846-856. [CrossRef] [PubMed]

222. Wishart, D.S.; Knox, C.; Guo, A.C.; Shrivastava, S.; Hassanali, M.; Stothard, P.; Chang, Z.; Woolsey, J. DrugBank: A comprehensive resource for in silico drug discovery and exploration. Nucleic Acids Res. 2006, 34, D668-D672. [CrossRef] [PubMed]

(C) 2018 by the authors. Licensee MDPI, Basel, Switzerland. This article is an open access article distributed under the terms and conditions of the Creative Commons Attribution (CC BY) license (http://creativecommons.org/licenses/by/4.0/). 